\title{
Lava penetrating water: Submarine lava flows around the coasts of Pico Island, Azores
}

\author{
Neil C. Mitchell \\ School of Earth, Ocean and Planetary Sciences, Cardiff University, Cardiff, Wales, UK \\ Now at School of Earth, Atmospheric and Environmental Sciences, University of Manchester, Williamson Building, \\ Oxford Road, Manchester M13 9PL, UK (neil.mitchell@manchester.ac.uk)

\section{Christoph Beier} \\ Max-Planck-Institut für Chemie, Mainz, Germany \\ Institut für Geowissenschaften, Christian-Albrechts-Universität zu Kiel, Germany \\ Now at ARC National Key Centre for Geochemical Evolution and Metallogeny of Continents, Department of Earth and \\ Planetary Sciences, Macquarie University, Sydney, NSW 2109, Australia
}

\section{Paul L. Rosin}

Cardiff School of Computer Science, Cardiff University, 5 The Parade, Cardiff CF24 3AA, UK

\author{
Rui Quartau \\ Departamento de Geologia Marinha, Instituto Nacional de Engenharia, Tecnologia e Inovação, Estrada da Portela, \\ Zambujal-Alfragide, Apartado 7586, Amadora, 2720-866, Portugal
}

Fernando Tempera

Departamento de Oceanografia e Pescas, University of the Azores, PT-9901-862 Horta, Azores, Portugal

[1] Bathymetry data collected with a multibeam echo sounder around Pico Island, Azores (Portugal), reveal a remarkable series of lava flows on the island's shelf with a variety of pristine structures that suggest how lava behaves on entering water. Many flows are dendritic in plan view, some with channels and tumuli. Dendritic geometries are interpreted to arise from flow fronts repeatedly arrested by enhanced cooling and magma pressure subsequently causing new breakouts. Cascades of elongated flow fingers also occur, with individual fingers of comparable diameters to the largest known megapillows. Some flows have wide transverse clefts, in cases separating flows into segments, which are interpreted as caused by their upper surfaces having solidified, while their still-fluid cores allowed the surfaces to extend. A number of flows moved onto the shelf as large bodies, stopped, and then sourced smaller lobes forming the dendritic patterns. This two-stage evolution and the tumuli (which lie on a low gradient immediately below a steep nearshore gradient) suggest that, after initial emplacement and development of a crust by cooling, some flows pressurized. Once movements ceased and viscous stresses dissipated, magma static pressure developed from the weight of flow interiors passing over cliffs and nearshore gradients. One group of flows traverses the island's submarine slope, so direct supply of lava to the slopes is possible, although volumetrically how important it is to the island's internal composition is difficult to tell from these data. On the basis of observed strong surf erosion of historical flows, these delicate structures probably could not have survived passage through a moving sea level unmodified by erosion so they are unlikely to be preHolocene subaerial flows. They are interpreted to have formed in the Holocene from flows penetrating sea 
level or possibly some from nearshore tube openings or vents. Such flows and abundant clastic deposits are ephemeral features that become remobilized by surf during times of lower sea level. The shelves of active volcanic islands are therefore active geologically and are far from being simple products of erosional truncation as was once envisaged.

Components: 16,386 words, 20 figures.

Keywords: submarine lava flow; volcanic ocean island; tumuli; lava channel; volcanic landslides.

Index Terms: 8429 Volcanology: Lava rheology and morphology; 8427 Volcanology: Subaqueous volcanism; 8425 Volcanology: Effusive volcanism.

Received 15 June 2007; Revised 31 October 2007; Accepted 8 November 2007; Published 27 March 2008.

Mitchell, N. C., C. Beier, P. L. Rosin, R. Quartau, and F. Tempera (2008), Lava penetrating water: Submarine lava flows around the coasts of Pico Island, Azores, Geochem. Geophys. Geosyst., 9, Q03024, doi:10.1029/2007GC001725.

\section{Introduction}

[2] The submerged parts of predominantly basaltic volcanic ocean islands are typically much larger than their visible parts above sea level, but difficulty of observation has led to diverging views on whether their submarine slopes comprise mainly volcaniclastic debris or lava. Early work based on subglacially erupted volcanoes suggested that the submerged parts of islands probably consist of debris foresets from fragmentation of lava erupted or flowing into shallow water overlying a pillow lava core [Jones, 1966; Moore and Fiske, 1969]. A similar view has dominated concerning Hawai'i, where the smooth morphology of the submarine slope of Kilauea, largely comprising volcaniclastic debris, appeared to be simply explained by observations of lava fragmenting where it over spills coastal cliffs into surf [Moore and Chadwick, 1995]. In the Canary Islands, field observations of an uplifted seamount revealed volcaniclastic material of explosive eruptions as the edifice grew toward sea level, overlying a pillow-dominated sequence from deep submarine eruptions [Staudigel and Schmincke, 1984], and drilling around the islands recovered abundant volcaniclastic debris [Schmincke et al., 1995].

[3] Kilauea, which dominates the literature on this subject, has an extreme rate of magma extrusion [Clague and Dalrymple, 1989], and a number of observations suggest that the above views are not necessarily representative of all ocean islands. Although the slope around Kilauea largely comprises clastic debris, pillow lava was the dominant type found in dives around Moana Loa [Fornari et al., 1979; Garcia and Davis, 2001; Garcia et al., 1995; Heezen, 1977]. Sulphur concentrations of some lava emplaced deeply on the flank of Moana Loa are remarkably low, interpreted as the lava having degassed subaerially before being emplaced [Davis et al., 2003; Garcia and Davis, 2001; Garcia et al., 1995]. Some low-sulphur lavas were erupted from nearshore vents [Fornari et al., 1980; Wanless et al., 2006] while other lavas have been mapped crossing the coast [Moore and Clague, 1987; Moore et al., 1985]. Samples recovered by drilling through the coastal sequence of Moana Kea and Moana Loa also suggests volcaniclastic debris deposited down to only $\sim 600 \mathrm{~m}$ original water depth overlying pillows [Garcia et al., 2007]. Submarine slopes of islands can have bulbous morphologies as though produced by volcanic extrusive processes [Clague et al., 2000; Mitchell et al., 2002; Moore and Chadwick, 1995].

[4] The possibility exists, therefore, that a proportion of the submarine parts of volcanic islands comprises lava originated from land that has passed through the surf and was emplaced at depth via lava tubes or flows. This connection between subaerial and submarine geology has remained obscure because of a lack of observations in nearshore regions as surveying requires specialized vessels. Lacking such data, Menard [1986], for example, considered the morphology of the shelves of active islands to be the result of surf erosion, neglecting lava depositional processes occurring on the shelf itself, an approach also reflected in work on the Canary Islands [Carracedo et al., 1999].

[5] Although observing small areas, scuba diver reports of lava tongues and lobes produced during the 1969 and 1971 eruptions of Kilauea [Moore et al., 1973] are informative. They included one 'a'a flow that passed beyond $70 \mathrm{~m}$ depth and several hundred meters offshore, while sourcing several 


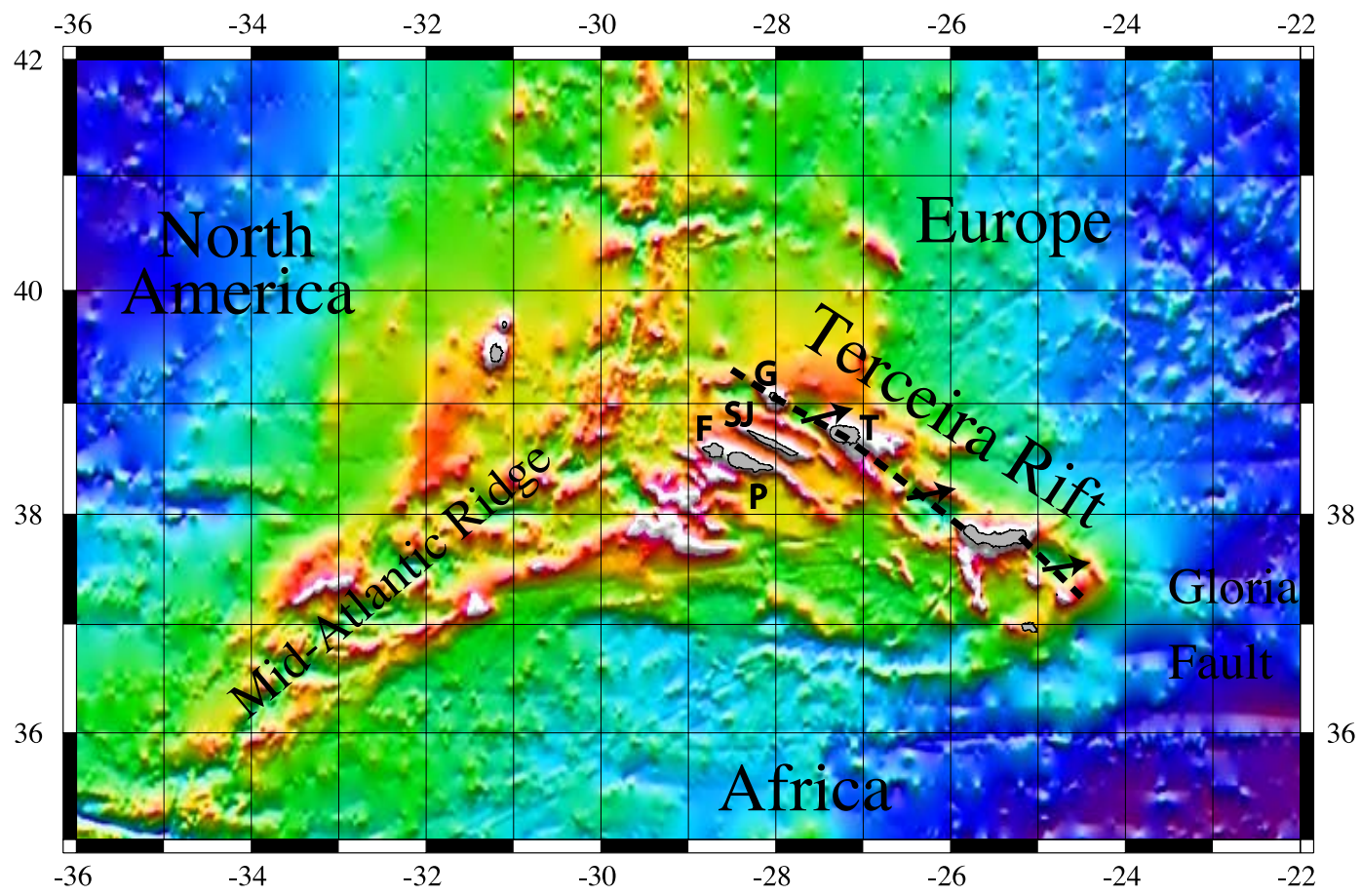

Figure 1. Regional bathymetry of the Azores islands (colors represent depths from $5300 \mathrm{~m}$ (dark purple) to $750 \mathrm{~m}$ (white/magenta)). Annotations P, F, SJ, G, and T locate Pico, Faial, São Jorge, Graciosa and Terceira islands, respectively. Vectors represent the Europe-Africa plate motion derived from $\sim 10$ Ma Chron 5 reconstruction poles [Müller and Roest, 1992].

finger-like extrusions laterally. Pahoehoe lava was found mostly to build a clastic slope from lavawater interactions at the shoreline, but some lobes penetrated below water and sourced pillow lavas and lobes during large flow discharge, where cliffs at the water edge were unusually low or where lava was protected from surf. In 1989, 0.7- to $1.5-\mathrm{m}$ wide lava streams on the delta front were seen emanating from surf-traversing flows or tubes [Tribble, 1991]. Moore and Clague [1987] reported cylindrical tongues up to $6 \mathrm{~m}$ in diameter crossing reefs off North Kona of Hawai'i. Arculus [1973] reported observing pillows to $30 \mathrm{~m}$ depth off Etna in Sicily. Actively growing coastal pillows were observed from a boat in 1905 along the shore in west Samoa [Anderson, 1910]. According to Peterson [1976], littoral tubes can form where lava crosses a shallow coastal cliff and its crust freezes when washed by a strong wave. He considered the development of stable tubes unusual because the lava can otherwise quickly freeze if the flow is small or be left with too thin a crust to withstand flow stresses if the flow is large. Nevertheless, because of the thermal protection provided by tubes [Greeley, 1987; Swanson, 1973], they provide a mechanism for efficiently transferring lava to below sea level and were the likely conduits of the 1989 pahoehoe flows [Tribble, 1991].

[6] Examples in geophysical data of lava flows penetrating below water level in lakes have been found on Iceland [Bull et al., 2005; Thors, 1992] and Japan [Umino, 2004], the latter showing surface folds and flow lobes. Umino et al. [2006] mention Japanese studies of 'a'a lava delta fronts which sourced fingers of lava in the water. In particular, field observations of lake-entering ' $a$ 'a flows near Mount Fuji [Obata and Umino, 1999], where subsequent water level fall has exposed lava structures subaerially, include flow lobes with 1- to 20-m-wide tumuli and branching flow lobes with connections to outer lobes through narrow conduits giving the appearance of frog's fingertips. These features are comparable to some we describe below. Subaerially originating flows have been mapped around Mauna Loa by submersible, sonar or inferred from gross morphology and sample geochemistry [Lipman and Moore, 1996; Moore and Fornari, 1984; Moore et al., 1985; Wanless et al., 2006].

[7] This contribution presents data collected in 2003 with a multibeam echo sounder around Pico Island of the Azores (Figures 1 and 2). Although 





Azorean volcanoes erupt compositionally diverse lava types [White et al., 1979], those of Pico are largely basaltic so it is a useful analogue for other basaltic ocean islands. The data show a variety of remarkably preserved lava structures on the island's shelf. After describing the data collection, the geology of the island is briefly outlined along with broad-scale submarine features in the data, followed by observations and discussion of factors affecting flow behavior that could have created these lava structures.

\section{Sonar Installation and Data Processing}

[8] The sonar, a Reson Seabat $8160^{\mathrm{TM}}$ multibeam echo sounder, is designed to measure acoustic traveltime to the seabed within 126 beams. Although the sonar's $50 \mathrm{kHz}$ acoustic frequency is intended primarily for medium water depths, the sonar performed well over the full range of water depths around the islands. In shallow water, signals from the reception beams are electronically focused on points along the beam axes before bottom detection, a facility that worked effectively to $10 \mathrm{~m}$ or less below the transducers. The sonar's transducer was mounted at the end of a rigid pole suspended below the bows of the University of the Azores R/V Arquipélago and secured with steel cables (Figure 2, top right inset). Vessel position and orientation was continuously recorded with an Applanix POS/MV ${ }^{\mathrm{TM}}$ motion sensor that combines information from an inertial navigation system (providing orientation and position) with GPS data for position as well as heading. GPS differential corrections from EGNOS satellite broadcasts were also continuously applied. In addition, the variation of sound speed with depth, needed for acoustic refraction corrections, was recorded with a Navitronic SVP-25 ${ }^{\mathrm{TM}}$ velocity probe. A Valeport gauge was installed for the duration of the fieldwork at Horta (Faial Island) to allow corrections for tides.
The relative orientation of sonar transducers and motion sensor was derived from data surveyed in two standard "patch test" calibration procedures, one outside Horta and another north of Pico.

[9] The data were processed using the CARIS/ HIPS $^{\text {TM }}$ software, which allows large groups of soundings to be viewed together simultaneously with different viewpoints for editing. Although the sonar performed well, noise bursts from the ship or other sources were frequently detected by the system as the bottom echo. These erroneous data were clearly identifiable as having anomalous gradients compared with the seabed (occurring at a common reception time) so were easily removed. They affected mostly the outer beams, which were also affected by a water column multiple of the transmitted pulse acting as further noise. A nonperfect rigidity of the transducer mounting may have contributed to an across-track striping in some data where the small vessel was pitching or yawing strongly.

[10] The nominal acoustic resolution of these data is constrained by the system's $1.5^{\circ}$ beam width. Over 10 to $100 \mathrm{~m}$ depth, it varies respectively from $26 \mathrm{~cm}$ to $2.6 \mathrm{~m}$ at nadir and from $52 \mathrm{~cm}$ to $5.2 \mathrm{~m}$ at $60^{\circ}$ off-nadir. However, the navigation precision and effects of imperfect transducer mounting also limit resolution, which is probably around $1 \mathrm{~m}$ for the nadir in shelf depths, deteriorating toward the swath edges as will be seen.

[11] Data were gridded within CARIS/HIPS ${ }^{\mathrm{TM}}$ using a simple binning algorithm that assigns each sounding to adjacent grid nodes with a weight decreasing with distance from the sounding. This generally works well with high data densities but creates artificial terracing on steep gradients where data are sparse. Grid node spacings were optimized for the size of area mapped: $25 \mathrm{~cm}$ for Figures $6-$ 10, 12 and 13; $1 \mathrm{~m}$ for Figures 11, 14, 16 and 17; and $25 \mathrm{~m}$ for Figure 2. The sonar also recorded acoustic backscatter data, which were mapped

\footnotetext{
Figure 2. Topography and bathymetry of Pico Island. Boxes indicate data examples in this paper and its associated auxiliary material (red outline boxes refer to main text figures and black outline boxes refer to auxiliary figures). Red areas outline historical flows [Neumann van Padang et al., 1967]. Yellow lines and blue areas outline the Lajes and Calheta do Nesquim volcanic series, respectively [Madeira and Brum da Silveira, 2003]. Profile in the northwest 1718 flow is shown in bottom left inset, with the submarine portion in red (the central flow in Figure 6). Red symbols mark rock sampling localities for the data shown in Figure 4 (those encircled were associated with their adjacent submarine flows). Map is in Universal Transverse Mercator projection (zone 26, WGS84). Distances along map boundaries are meters north of the equator and east of the projection meridian $\left(33^{\circ} \mathrm{W}\right)$ plus $500,000 \mathrm{~m}$. Arrows and annotation $\mathrm{p}, \mathrm{p}^{\prime}, \mathrm{q}, \mathrm{q}^{\prime}, \mathrm{r}, \mathrm{r}^{\prime}$ locate the geographical limits of the gradients calculated for Figure 5. Top right inset shows the bow installation of the multibeam sonar. Bottom right inset shows boomer seismic data from south of the island [Quartau et al., 2003].
} 


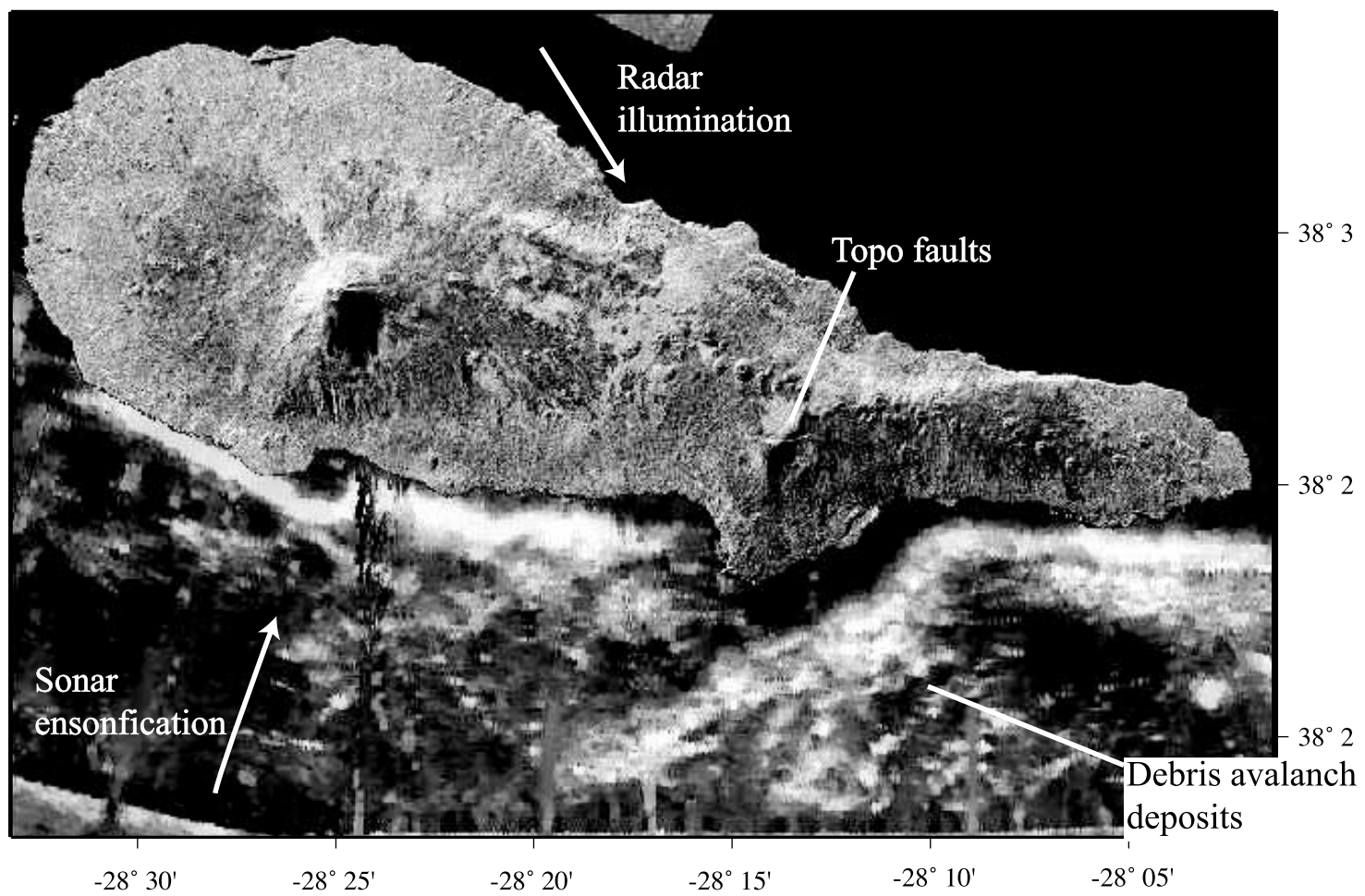

Figure 3. Image of Pico from Space Imaging Radar Band-C (SIR-C) combined with long-range side-scan sonar imagery offshore [Mitchell, 2003] showing the 1718 flow (Figure 2) and cones of the easterly ridge.

using the CARIS ${ }^{\mathrm{TM}}$ software and backscattering contrasts between bare rock and sediment guided interpretation.

[12] The resulting maps are shown in Universal Transverse Mercator projection (zone 25, World Geodetic System 1984 (WGS84)), so boundary coordinates provide scale in meters. A further set of maps with only grey shading (better for showing detail than color) is given in the auxiliary material ${ }^{1}$ along with relief cross sections. Topography and coastlines in Figure 2 were derived from local relief maps. Digital elevation data from the Shuttle Radar Topography Mission (SRTM) [Farr and Kobrick, 2000] provided a consistent data set for measuring gradients of the subaerial parts of the island.

[13] Selected areas of Pico island were sampled in 2003. Most samples are optically fresh and lack alteration of olivine crystals and vesicle fillings. Where glass was present, in a few samples, it was separated, washed and used for the geochemical analyses. Where glass was absent, fresh cores of samples were coarse crushed, washed in deionized water, and then fine crushed in an agate ball mill.

\footnotetext{
${ }^{1}$ Auxiliary materials are available in the HTML. doi:10.1029/ 2007GC001725.
}

For whole rock major element analyses, $0.6 \mathrm{~g}$ of dried powder of each sample were mixed with lithium tetraborate and ammonium nitrate, fused to a homogeneous glass bead, and analyzed at the Universität zu Kiel using a Philips 1400 XRF spectrometer calibrated against international rock standards. Precision was better than $0.8 \%$ and accuracy better than $1 \%$ of measured values.

\section{Geological Background}

[14] The central Azores islands lie around the Europe (EUR)-Africa (AFR) plate boundary [ Vogt and Jung, 2004] and across a broad plateau formed by the Azores melting anomaly [Schilling, 1975]. West of the Gloria Fault (Figure 1), as the Terceira Rift plate boundary is oblique to EUR-AFR plate motion, deformation is transtensional [Lourenço et al., 1998; Mitchell and Livermore, 1997], illustrated by the last $10 \mathrm{Ma}$ of motion in Figure 1 (vectors). EUR-AFR motion is probably not localized along the Terceira Rift, as tectonic structures and magnetic anomalies nearer to the Mid-Atlantic Ridge suggest movement independent of the larger plates [Freire Luis et al., 1994; Lourenço et al., 1998] and GPS data [Fernandes et al., 2006] and seismicity [e.g., Buforn et al., 1988] suggest some 


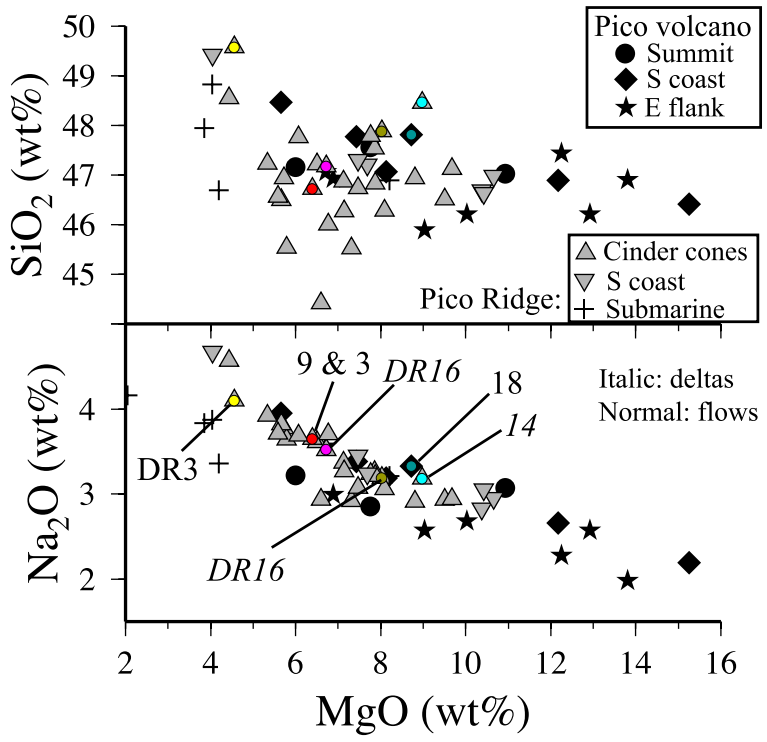

Figure 4. Whole rock $\mathrm{SiO}_{2}$ and $\mathrm{Na}_{2} \mathrm{O}$ versus $\mathrm{MgO}$ wt $\%$ contents of the submarine and subaeral Pico lavas. Subaerial localities are marked in Figure 2 (same symbols but red). Colored small circles mark samples that were associated with offshore flows and lava deltas using a geological map [Nunes, 1999] (normal and italic fonts, respectively, identifying the associated figures).

movement distributed throughout the central islands of Pico, Faial, São Jorge, Terceira and Graciosa. In an earlier expedition with deeply towed side-scan sonar, faults and volcanic ridges suggestive of dyke emplacements subparallel to the Terceira Rift were mapped around Faial, Pico, Terceira and São Jorge islands [Ligi et al., 1999; Stretch et al., 2006], confirming this hypothesis on the deformation.

[15] Pico Island comprises a stratovolcano rising above $2000 \mathrm{~m}$ altitude (Pico) and a ridge to its east, marked by a chain of cinder cones (Figures 2 and 3), extending below sea level [Stretch et al., 2006]. An older edifice forming the southern promontory is called Topo. Volcanic products are lava with minor cinders [Neumann van Padang et al., 1967]. The flows on Pico volcano include 'a'a and pahoehoe, whereas the eastern ridge is dominated by 'a' a [Scarth and Tanguy, 2001; Woodhall, 1974]. Parasitic cones are scattered around Pico's flanks (Figures 2 and 3). The historical lavas erupted in 1562,1718 and 1720 A.D. are shown in transparent red in Figure 2 [Neumann van Padang et al., 1967]. According to Nunes [1999] (available at http://www.uac.pt/ jcnunes/principal.htm), lavas of the northerly 1718 eruption (unusually mugearitic [França, 2002]) were largely 'a'a at the coast, whereas the 1562 lavas formed a low-relief delta of pahoehoe at the coast. He suggested that coastal pahoehoe and 'a'a are commonly associated with smooth and convoluted coastlines, respectively. His volcanological map (http://www.uac.pt/ jcnunes/ principal.htm) shows flows of Pico volcano originating largely from the summit area, though also some from flank sources. Those lavas and lavas emitted from the easterly ridge then flowed toward the coasts.

[16] Lavas have been classified as alkali basalts with minor hawaiites [França et al., 2006]. Figure 4 shows whole rock $\mathrm{SiO}_{2}$ and $\mathrm{Na}_{2} \mathrm{O}$ versus $\mathrm{MgO}$ contents derived from samples collected by us from the localities shown in Figure 2. Lavas follow a common liquid line of descent, as on other Azorean islands [Beier et al., 2006], although Pico's lavas tend to be less evolved. From the graphs, the ridge lavas are slightly more evolved on average and more diverse. The shallow level fractionation trend [Klein and Langmuir, 1987] results primarily from crystallization of olivine and clinopyroxene, and plagioclase and $\mathrm{Fe}-\mathrm{Ti}$ oxides in the more evolved lavas with $\mathrm{MgO}$ contents $<5$ wt \%. Lavas from Pico volcano have slightly higher $\mathrm{MgO}$ contents than lavas from the ridge. $\mathrm{MgO}$ contents greater than $12 \mathrm{wt} \%$ probably result from accumulation of olivine and clinopyroxene, as those lavas contain abundant olivine and clinopyroxene xenocrysts. The lavas we describe below are therefore primarily alkali basalts with varying degrees of olivine and clinopyroxene fractionation and probably decreasing eruption temperature with decreasing $\mathrm{MgO}$.

[17] The following chronology is taken from Madeira and Brum da Silveira [2003], but generally follows other sources [França, 2002; França et al., 2006; Nunes, 1999; Scarth and Tanguy, 2001; Walker, 1973; Woodhall, 1974; Zbyszewski et al., 1963]. The oldest parts of the island are associated with the Topo volcano and form the Lajes volcanic complex outlined in yellow in Figure 2. Madeira and Brum da Silveira [2003] mention a single $\mathrm{K} / \mathrm{Ar}$ date of $250 \pm 40 \mathrm{ka}$ for this unit from Chovelon [1982]. A pre-Holocene age is consistent with the nearshore topography, which comprises terraces of probable erosional origin created during earlier periods of lower sea level (Figure S15 in the auxiliary material). The next unit emplaced was the Calheta do Nesquim volcanic complex, which comprises basaltic Strombolian scoria cones and lava flows cropping out over easterly parts of the island ("Cn" in transparent 


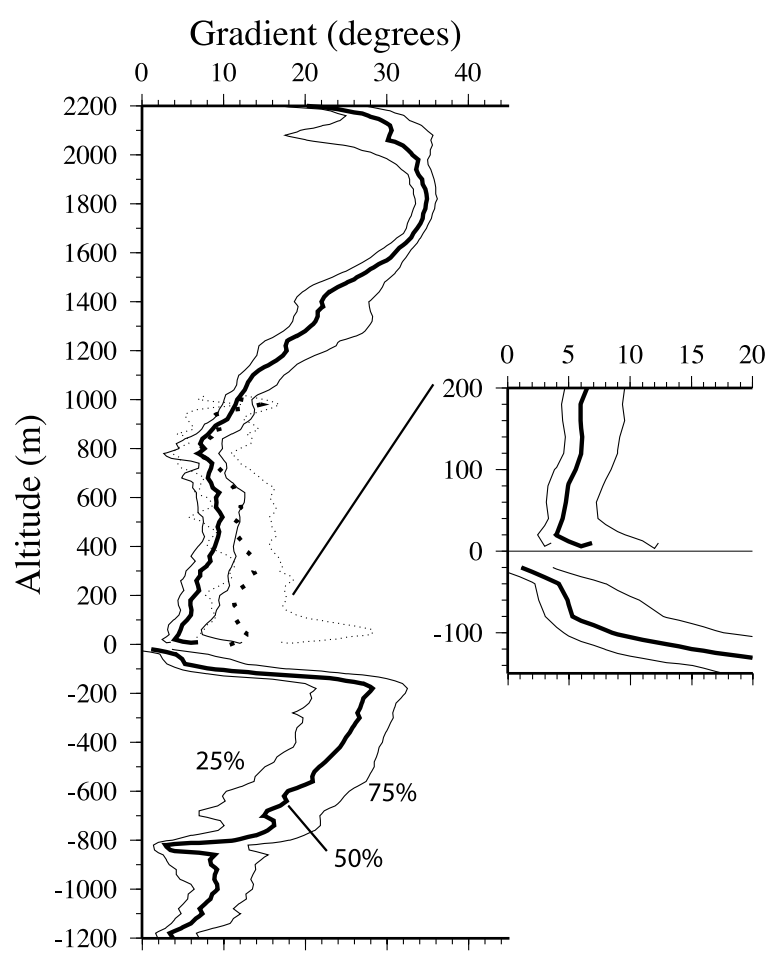

Figure 5. Gradient profile of Pico island calculated for the region between the two pairs of arrows marked p-p' and $\mathrm{q}-\mathrm{q}^{\prime}$ in Figure 2 using the method of Mitchell et al. [2002]. Gradients computed from the topography were sorted into $20-\mathrm{m}$ altitude or depth intervals and the median $(50 \%)$ and interquartile range $(25 \%, 75 \%)$ of the data found within each depth interval. The solid lines above sea level represent gradients calculated from SRTM data over Pico volcano (between $p-p^{\prime}$ and $q-q^{\prime}$ in Figure 2) and the dashed lines represent gradients calculated from SRTM data over the easterly part of the island (between $\mathrm{q}-\mathrm{q}^{\prime}$ and $\mathrm{r}-\mathrm{r}^{\prime}$ in Figure 2). Inset shows the shallow water interval enlarged.

blue in Figure 2). K/Ar ages vary from $270 \pm$ $150 \mathrm{ka}$ to $<25 \mathrm{ka}$ [Chovelon, 1982; Feraud et al., 1980]. As some uneroded lava units occur immediately offshore (e.g., Figure 11), emplacement of this unit likely continued into the Holocene. The last unit emplaced, covering most of the island, is the Madalena volcanic complex. Radiocarbon dates suggest a Holocene age for this unit [Madeira and Brum da Silveira, 2003; Nunes, 1999], which is confirmed by the nearshore lava structures mapped in this study. Older units may be obscured in the Madalena complex mapped by Madeira and Brum da Silveira [2003] also, as high sea cliffs to north and south of the eastern ridge imply an extended period of erosion by surf and [Nunes, 1999] mentions a $>200 \mathrm{ka}$ sample attributed to Chovelon [1982] in the sea cliff immediately east of Figure S18, where nearshore lava structures are generally lacking.

\section{Gross Morphology}

[18] Submarine features in Figure 2 include abundant cones, particularly on the southeast continuation of the easterly ridge [Stretch et al., 2006]. The island's submarine slopes are gullied but with minor relief, e.g., compared with up to $200 \mathrm{~m}$ on the 6-8 Ma slopes of Tenerife [Mitchell et al., 2003], consistent with Pico's young age. Volcanic ridges with associated cones extend southwest and south of Topo $(390000 \mathrm{mE}, 4248000 \mathrm{mN})$. The shallow channel between Pico and Faial islands contains active faults (in particular, at $4267000 \mathrm{mN}$ ) and abundant lava flows, particularly near to Pico volcano, including open tubes located by divers [Cunha, 2001]. A series of remotely operated vehicle (ROV) dives have been made west of Pico for biohabitat characterization purposes. Although not coinciding exactly with the features described in this paper, they do reveal a variety of lava types, including blocky surfaces typical of 'a'a lava and smoother (some ropey), flatter lobate surfaces typical of large flattened pillows or submarine lobate flows found elsewhere [Umino et al., 2000]. A boomer seismic survey around the island's coasts in 2002 found abundant sediments, which sampling showed to be sand and gravel grade, compositionally varied biogenic and volcanic particles [Quartau et al., 2003, 2005]. The ROV photographs show both white and black sand. A synthesis of the boomer data will be presented elsewhere but a lava structure buried by sediment is shown in Figure 2, bottom right inset, and elsewhere these data show that many of the lava structures shown here were emplaced over shelf sediment.

[19] Figure 5 shows a graph of median and interquartile range of surface gradients. Gradients were computed [Wessel and Smith, 1991] from the bathymetry over a 50-m length scale, from the area between the arrows marked p- $\mathrm{p}^{\prime}$ and r-r ${ }^{\prime}$ in Figure 2 (i.e., excluding unwanted bathymetry of the FaialPico channel and the easterly ridge). The submarine data represent only areas surveyed, excluding gaps represented by grey in Figure 2. To reduce effects of scan line irregularities, the SRTM data were first filtered with a $200-\mathrm{m}$ moving average (resolution is poorer than for the submarine data). Continuous and dotted lines above sea level in Figure 5 represent gradients calculated over Pico volcano (between $\mathrm{p}-\mathrm{p}^{\prime}$ and $\mathrm{q}-\mathrm{q}^{\prime}$ in Figure 2) and 


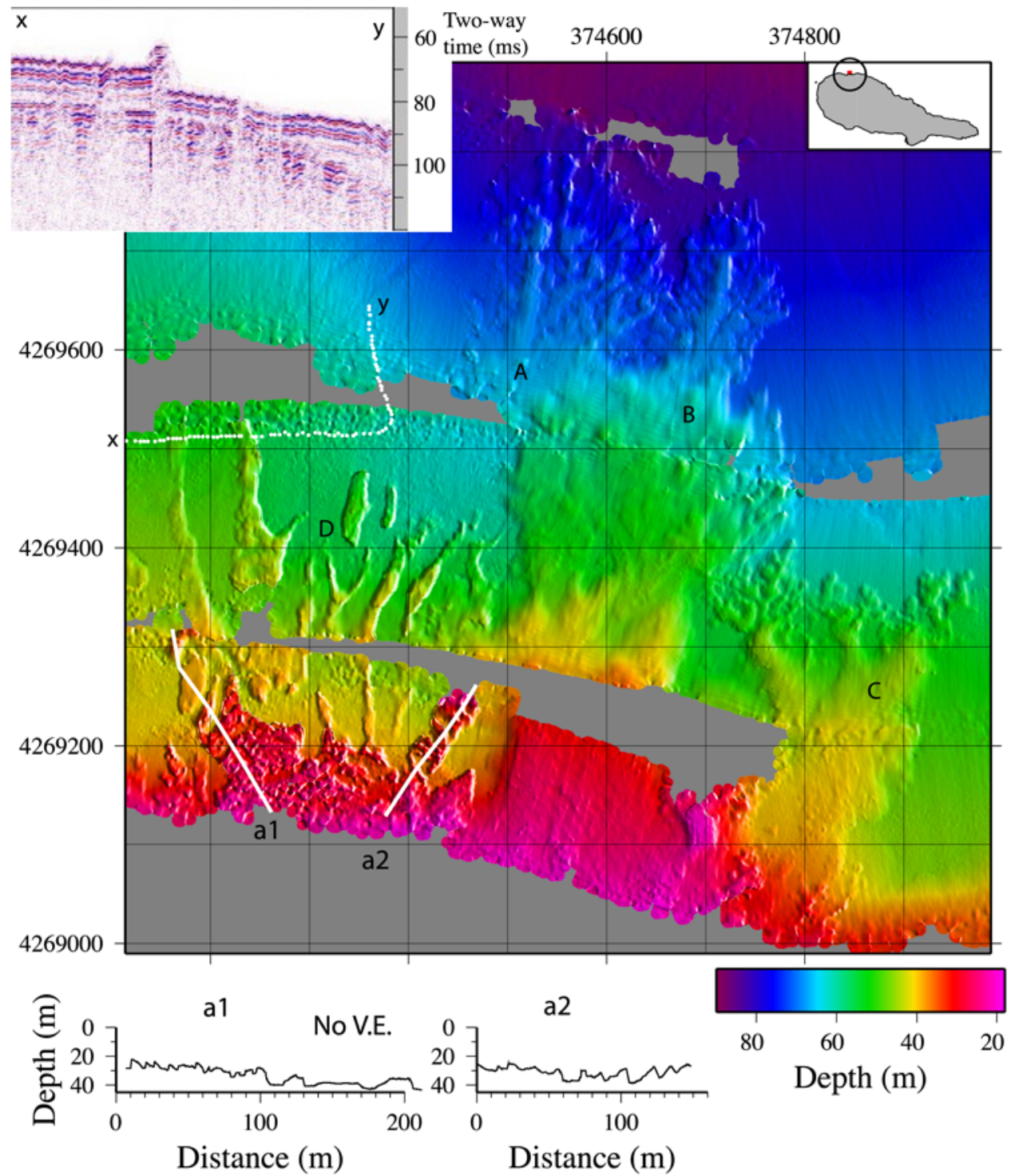

Figure 6. Three sets of flows on the northwest of the island. Shallow parts of the west flows (above $40 \mathrm{~m}$ depth) show transverse clefts, which are revealed by the two cross sections a1 and a2 in the lower left. The central (A, B) and easterly (C) flows appear to have moved onto the midshelf as relatively massive units, leaving flow fronts, but farther beyond them are dendritic patterns of elongate lobes. Grey shaded image and further cross sections are shown in Figures S6a and S6b. Top left inset shows a section of boomer seismic data collected on the track $\mathrm{x}-\mathrm{y}$ marked.

over the easterly part of the island (between $\mathrm{q}-\mathrm{q}^{\prime}$ and $r-r^{\prime}$ in Figure 2), respectively.

[20] The graph for Pico volcano steepens with altitude resembling Galapagos volcanoes Cerro Azul, Fernandina and Wolf [Mouginis-Mark et al., 1996], although the upper gradients here are steeper $\left(>30^{\circ}\right)$ than in the Galapagos $\left(20^{\circ}\right)$. Pico is steep because of many small summit eruptions developing compound flows [Walker, 1973; Woodhall, 1974] rather than major flows able to travel long distances as on Hawai'i. The lower volcano flanks are shield-like, declining in gradient toward sea level, whereas the upper slopes form a steep stratovolcano. Gradients on the east part of the island are generally steeper, reflecting the steep slopes paralleling the coasts of the easterly ridge.

[21] The submarine flanks of Pico are steepest just below the shelf break (median gradient $28.3^{\circ}$ at $180 \mathrm{~m}$ depth) and shallow toward the island base, an upward concave morphology similar to those of other islands [Mark and Moore, 1987; Mitchell et al., 2002]. The profile is more analogous to constructional flanks of such islands than to flanks that have failed in catastrophic landslides, which gen- 


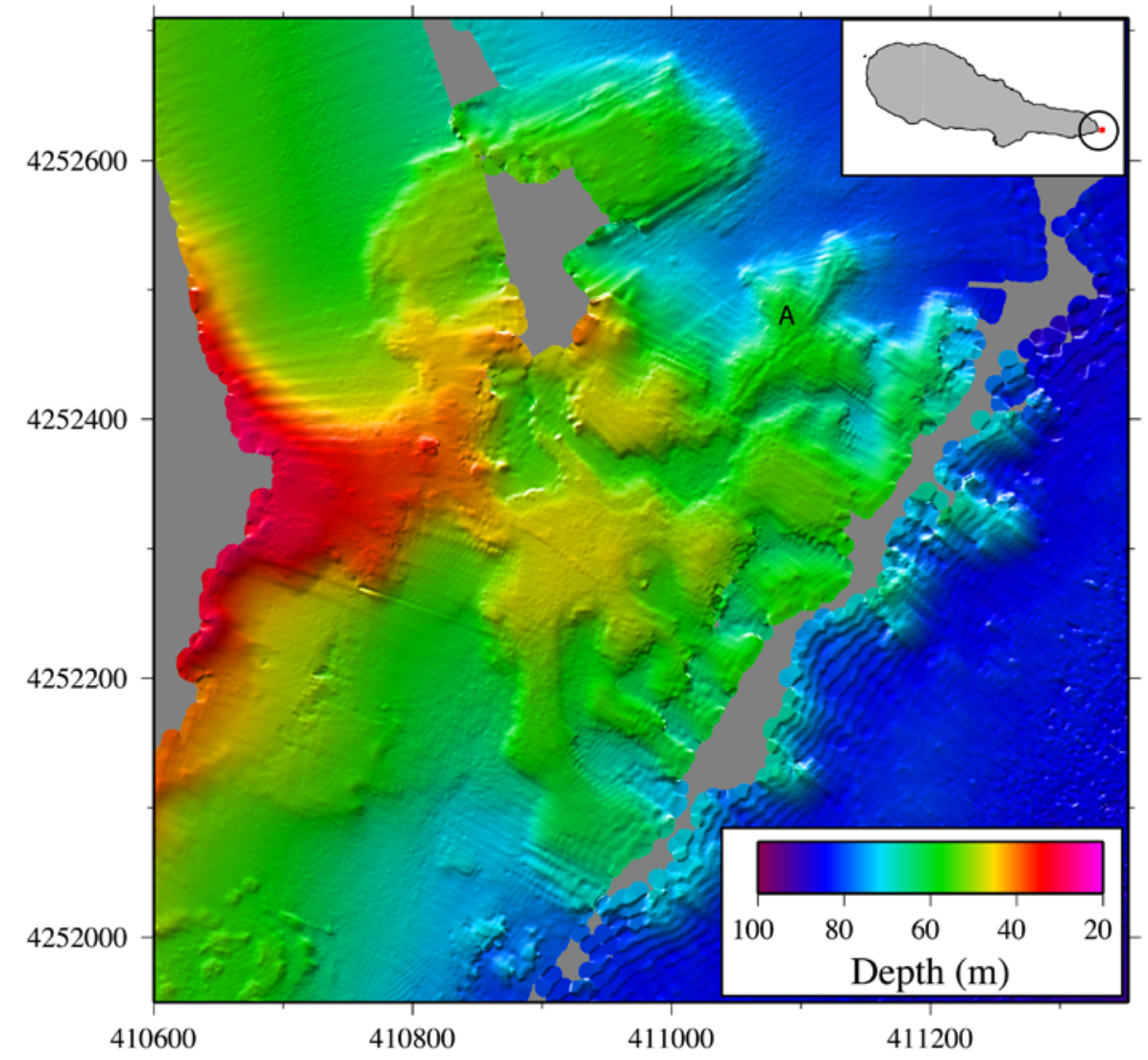

Figure 7. Cauliflower-shaped flows. Note axial depression along flow at " $A$ " but otherwise flat, smooth surfaces. Cross sections and grey shaded image are shown in Figure S7.

erally have smaller gradients [Mitchell et al., 2002]. This is consistent with an interpretation of earlier data in which the Azores lack the kinds of major landslides that have affected other ocean islands [Mitchell, 2003]. According to Lee et al. [1994], concave upward slopes of Hawai'i are caused by young debris at the top of slopes being near to its angle of repose, while material farther downslope has been mobilized by earthquakes so its gradient represents a seismically modified repose. Alternatively, slope curvature reflects debris run-out as inferred for subaerial scree slopes [Selby, 1993].

[22] A field of blocky material occurs below a convex part of the northern slope at " $A$ " in Figure 2. Its morphologic similarity to the west slope of La Palma [Urgeles et al., 1999] suggests a debris avalanche fan. Alternatively, it arises from repeated failure of lava deltas when earlier volcanism developed the rounded shelf break. The possibility that some blocks are volcanic cones cannot be excluded, however. Blocky material also occurs west of Topo ("B"), where it may also be related to volcanism, and southeast of Topo ("C"), below a previously identified collapse [Cruz and Silva, 2001] that formed the Topo faults marked in the radar image in Figure 3.

\section{Observations}

\subsection{Dendritic-Like Lava Flows}

[23] In Figure 6, a series of flows can be seen with dendritic (branching) terminations. The central flows form a section $200 \mathrm{~m}$ wide and $20 \mathrm{~m}$ thick (Figure S6b) that traveled from $20 \mathrm{~m}$ to $60 \mathrm{~m}$ water depth, beyond which lie two main branches of distal flow lobes (A, B in Figure 6), reaching beyond $80 \mathrm{~m}$ depth. Individual distal lobes have 5-10 m vertical relief. Gradients vary little between the two sections; those of the 200-m-wide flow are $2^{\circ}-5^{\circ}$ and trunk sections of the distal lobes are $3^{\circ}-4^{\circ}$. On the easterly side of the map, a similar series of three main lobes and dendritic branches can be observed with comparable dimensions and gradients. Although the massive flows and the distal branches could be fortuitously associated, we suggest that at least those at $\mathrm{B}$ and $\mathrm{C}$ were probably fed by the more massive flows. 


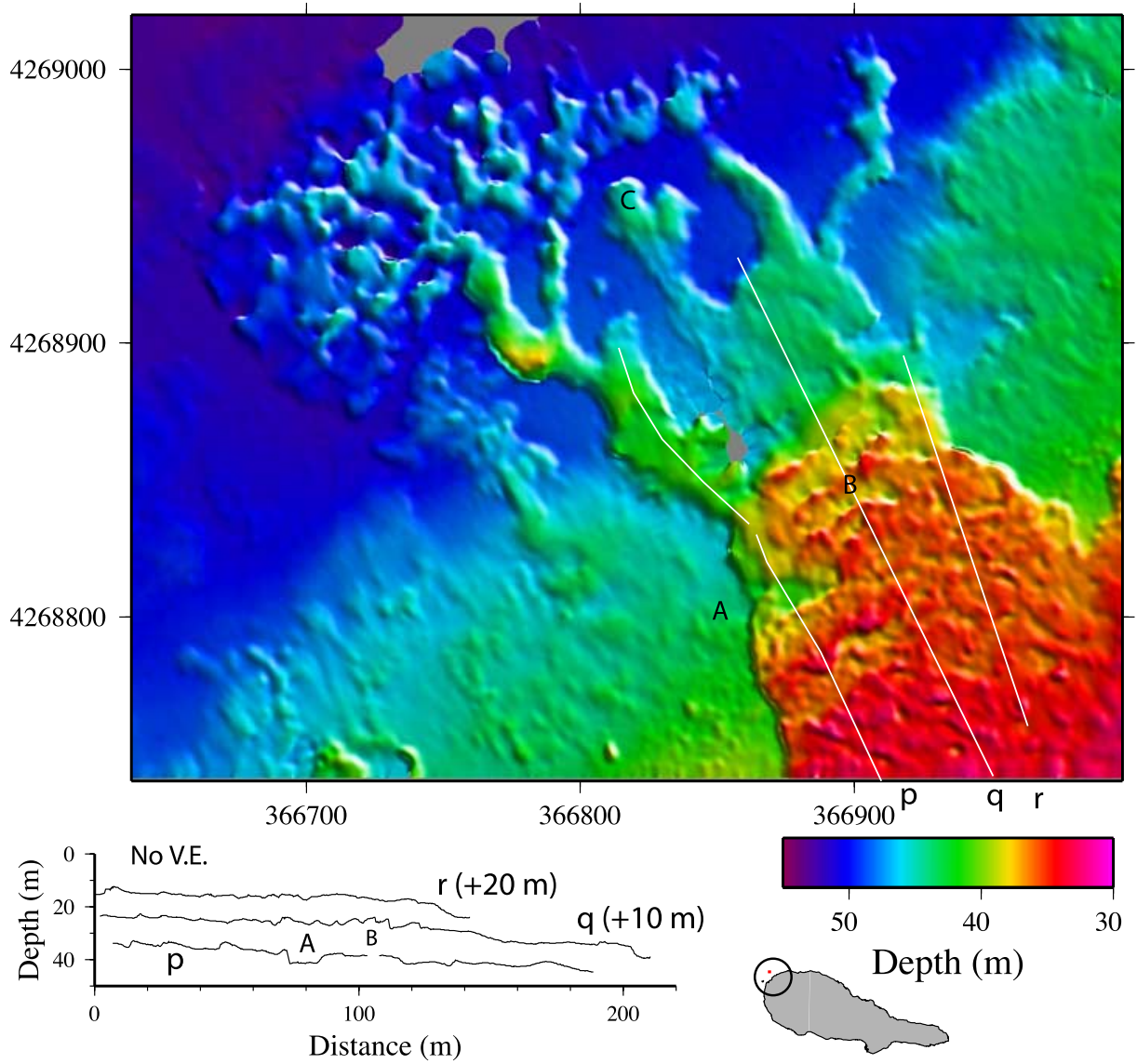

Figure 8. A 100-m-wide flow terminating in a series of narrower flows that in turn sourced a dendritic pattern of lobes. Upstream (above $40 \mathrm{~m}$ depth) the flow is disrupted by a series of open fractures, and downstream the channels have abruptly collapsed (note features close to the north of the map could be artefacts of noise in the sonar's outer beams). Three cross sections $\mathrm{p}, \mathrm{q}$ and $\mathrm{r}$ are shown to the bottom left. Further cross sections and grey shaded image are shown in Figure S8.

[24] Figure 7 shows a cauliflower-shaped series of flows extending from $20 \mathrm{~m}$ to $80 \mathrm{~m}$ depth. At $\sim 60$ m depth near " $A$ " in Figure 7, a longitudinal depression suggests a channel or expansion cleft. In shallower depths, the flow surfaces are surprising smooth and have low acoustic backscattering. Other dendritic flows are common in the multibeam sonar data set, e.g., Figures 8 and S20. Such branching patterns are analogous to those in the Japanese lake observations [Obata and Umino, 1999].

\subsection{Lava Flow Cascades}

[25] In Figure 9, a series of narrow flows form a cascade, as though sourced from points distributed along the nearshore. In cross sections (Figure S9), the flows have $\sim 5 \mathrm{~m}$ vertical relief and $\sim 20 \mathrm{~m}$ widths. The main flow sections have downflow surface gradients of mostly $2^{\circ}-3^{\circ}$, but steepen to $15^{\circ}$ in the western group. Flow toes reach $20^{\circ}-$ $25^{\circ}$. Cascades were also observed in the north of the island and farther east of Figure 9 (Figure S19, with $5^{\circ}$ gradients).

[26] Although larger, these flows are analogous morphologically to sketches by W. B. Bryan of pillow tubes in steep flow fronts on mid-ocean ridges [Basaltic Volcanism Study Project, 1981]. They are larger than megapillows measured up to 6 $\mathrm{m}$ in diameter on Cyprus by Schmincke and Bednarz [1990] but compare with the largest pillow dimensions compiled by Walker [1992]. Their apparently distributed sourcing along the nearshore is analogous to that in the Japanese lake observations [Obata and Umino, 1999].

\subsection{Tumuli and Lava Channels}

[27] Figure 10 shows two tumuli with crests lying at $40-50 \mathrm{~m}$. As seen in other settings [Calvari and Pinkerton, 1999], they lie at the base of a steep 


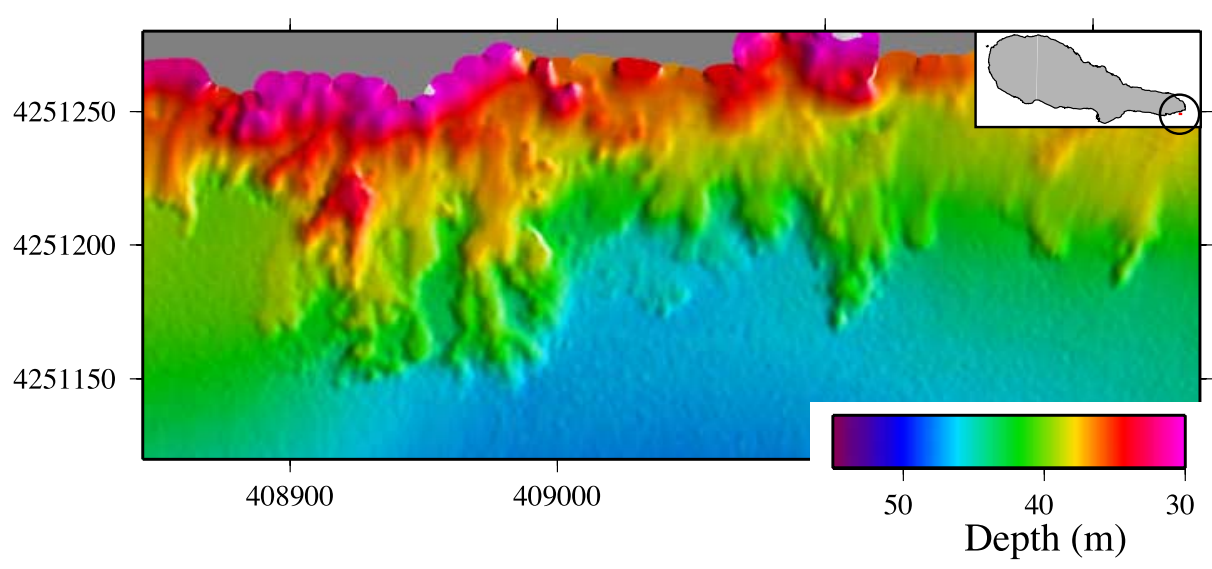

Figure 9. A cascade of flow lobes. Cross sections and grey shaded image are shown in Figure S9.

gradient, which is probably the foreset of a lava delta. From the two cross sections, the outer sides of the tumuli have $30^{\circ}$ gradients. The $10-20 \mathrm{~m}$ widths of their gapes roughly correspond to the amount of inflation, based on simple reconstruction [Walker, 1991]. Their height-to-width ratios are around $0.2-0.25$, within the range of aspect ratios compiled by Walker, but they are larger than the tumuli he studied. They are similar in size to other reported submarine tumuli [Applegate and Embley, 1992] but larger than reported submarine inflated flow lobes [Umino et al., 2000, 2002]. In Figure 10 and the cleft in the distal lobes of Figure 7, the main fracture is longitudinal, a feature also of subaerial 'a'a tumuli [Duncan et al., 2004].

[28] Figure 10 shows two or more channels. One emanating from the easterly tumulus (at "A") formed when its crust broke allowing lava to spill

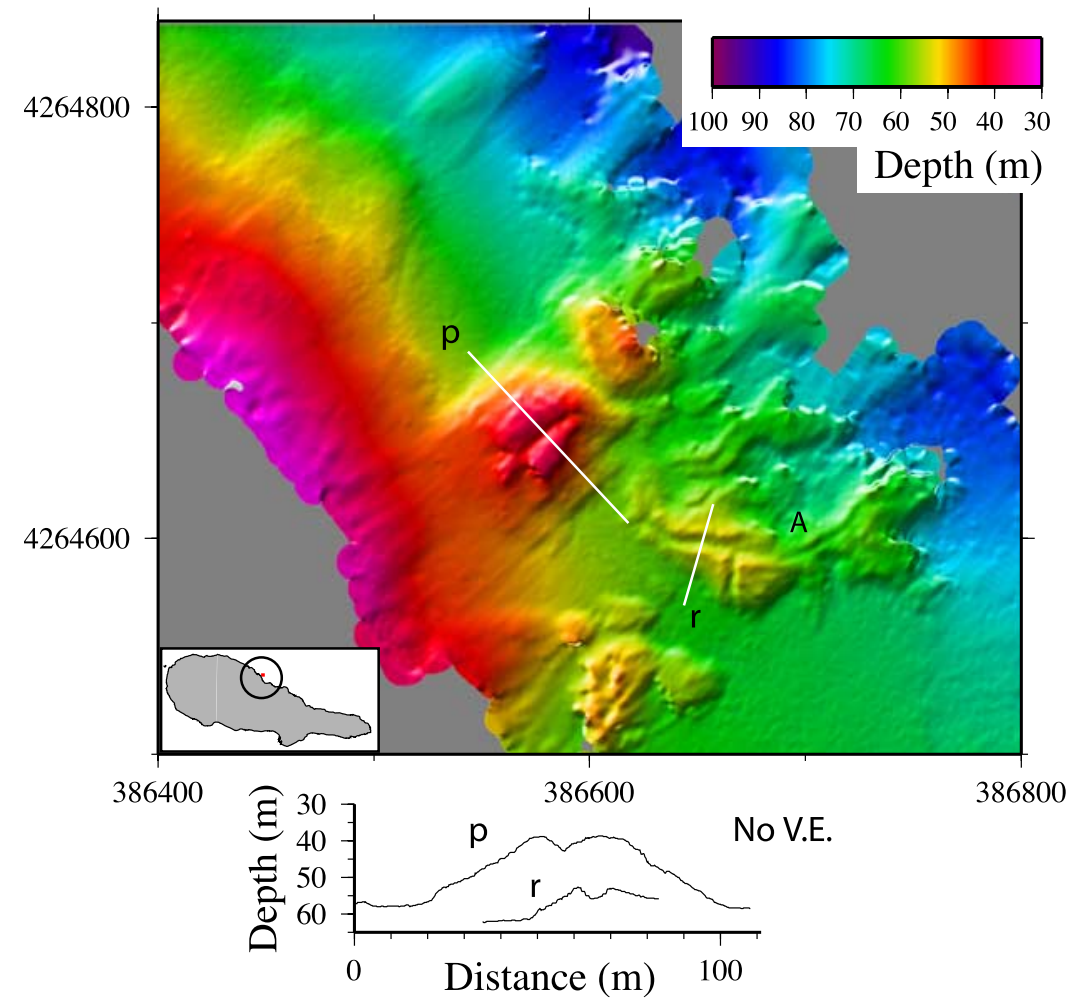

Figure 10. Tumuli and channels lying at the base of a steep slope, which is probably an eroded lava delta. The two cross sections $\mathrm{p}$ and $\mathrm{r}$ are shown with no vertical exaggeration. Further cross sections and grey shaded image are shown in Figure S10. 


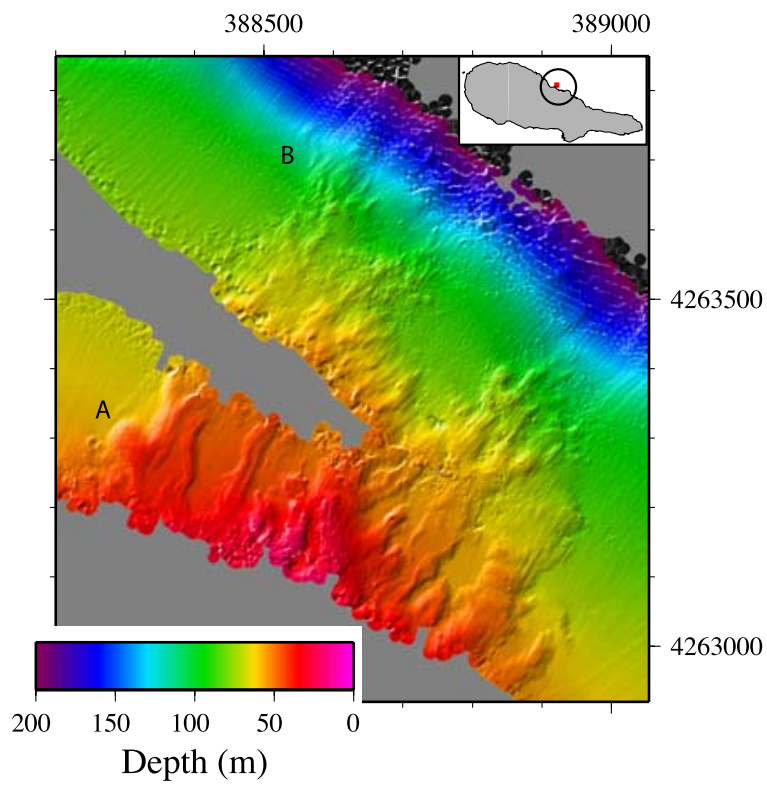

Figure 11. Flows showing channels and fingers reaching the shelf edge. One lobe at $40 \mathrm{~m}$ depth on the west (at "A") has inflated but not broken. Cross sections and grey shaded image are shown in Figure S11.

out. Further channels can be seen in Figure 11. Levees are recognizable in these images. In cross sections (Figures S11 and S10), the channels with their levees have a vertical relief of $5 \mathrm{~m}$ or less and are 20-50 m wide, comparable to dimensions of subaerial lava channels. Flow-wise gradients are $\sim 5^{\circ}$.

\subsection{Surface Folds}

[29] Figure 12 shows a 7-m-thick flow lying at only $20 \mathrm{~m}$ depth. Curved transverse ridges of $2-$ $3 \mathrm{~m}$ relief are interpreted as surface folds displaying drag structures, most easily seen in the grey image (Figure S12). Surface folds are spaced irregularly, on average by around $6 \mathrm{~m}$. This is shown by a variogram computed from the cross section after removing the trend line. Variograms are functions of serial data designed to reveal periodicities or, if stochastic, the distance over which any pair of points in the series looses correlation [Davis, 2002]. Variograms computed from these data suggest some periodicity but are strongly stochastic (see caption to Figure S12).

\subsection{Transverse Clefts}

[30] Some lava flows north and northwest of Pico volcano have major clefts oriented perpendicular or oblique to the flow axis. For example, the cross sections a 1 and a 2 in Figure 6 show that the lava surface opened to depths of $10 \mathrm{~m}$ or more, a major part of the flow thickness. In places, clefts have square bases and are probably sediment filled (e.g., at $110 \mathrm{~m}$ in a1). In others, they are V-shaped (e.g., at $130 \mathrm{~m}$ in a2). The clefted flows in Figure 6 appear to source the series of flows without clefts lying up to $200 \mathrm{~m}$ northward.

[31] The upstream parts of the dendritic flows in Figure 8 also show transverse features (see also Figure S8i). At "A" along profile $p$ there is a flatfloored cleft that forms a $40^{\circ} \mathrm{V}$-shaped depression in plan view suggesting a scissor-like opening. On profile q, a series of clefts at " $B$ " form asymmetric ridges with steep sides both up and down flow.

[32] In Figure 13, clefts are generally transverse to the flow orientation but curved in plan view, somewhat like the geometry of pahoehoe folds. One cleft at " $\mathrm{A}$ " in profile $\mathrm{q}$ is $15 \mathrm{~m}$ deep and V-like but with curved inner surfaces similar to those within tumuli clefts [Walker, 1991]. Profile p also shows a sharp V-shaped cleft. Other narrower flows in the east side of the map show transverse structures. Flow-wise gradients over segments encompassing these clefts are unexceptional, ranging from $2^{\circ}$ (Figure S8) to $7^{\circ}$ (Figures S6 and S13).

\subsection{Abrupt Terminations of Lava Flows}

[33] Flow relief abruptly terminates in a number of places. In Figure 8, several flows end abruptly in sediment-covered seafloor. One example separates a main flow branch from distal toes (at "C"). Other examples, some apparently breaking flow paths, occur in Figures 6 ("D") and 13 ("B"). Possible explanations include varied flow inflation leaving gaps in relief like lava rise pits [Gregg and Chadwick, 1996; Hon et al., 1994; Walker, 1991], collapse of hollow tubes (which can reach several meters across where located by divers around Pico [Cunha, 2001]) or disruption by normal faults. Discrimination among these possibilities will require more detailed observations.

\subsection{Lava Deltas}

[34] Figure 14 encompasses the area where lava of 1562-1564 A.D. entered the sea [Scarth and Tanguy, 2001] and the subaerial lava forms a low-relief delta of pahoehoe [Nunes, 1999]. In several such locations, terraces occur near to the shore. They have upper moderately dipping top surfaces lying at 20-30 m depth (e.g., at " $A$ " in Figure 14), which have a rugged small-scale mor- 


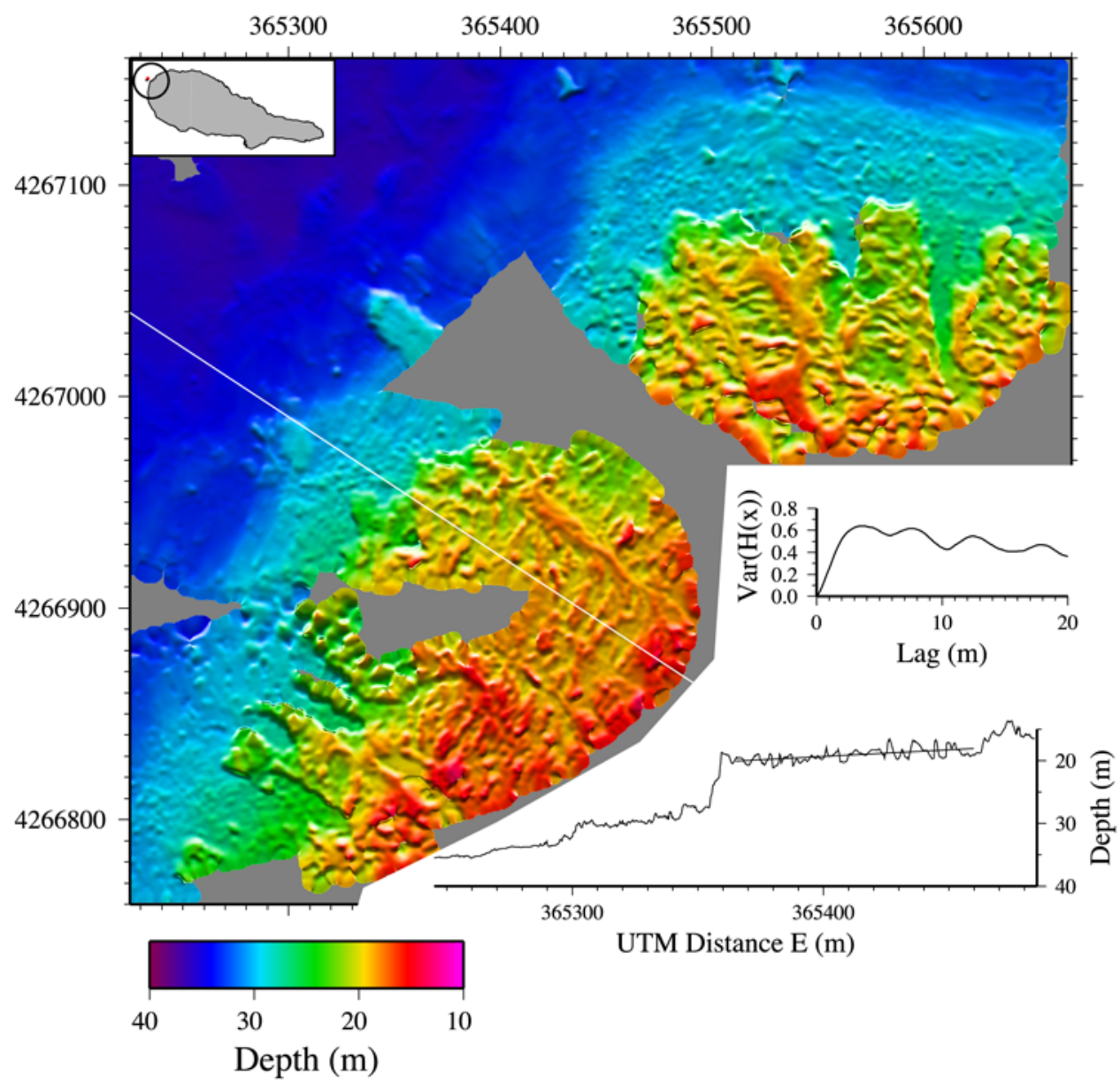

Figure 12. Flows with surface ridges interpreted as folds of a rigid upper surface. The average fold spacing was resolved from the variogram shown in the inset, which was calculated from the data cross section shown after detrending. (See caption to Figure S12, which also shows further cross sections and grey shaded image.)

phology and are highly backscattering acoustically. Surface dips are typically $4^{\circ}-7^{\circ}$. Seaward of the terrace, the seabed dips $25^{\circ}-35^{\circ}$, typical of gradients of basaltic talus ramps in other earthquakeprone areas [Mitchell et al., 2000; Moore et al., 1973; Tribble, 1991]. Although some shallow gullies occur on the east facing slope at "B" in Figure 14, most of these slopes are smooth and only weakly eroded.

[35] Such nearshore terraces are interpreted as lava deltas, in which volcaniclastic debris comprising the bulk of the delta [Moore et al., 1973] is easily eroded by surf. The depths of the terraces edges are comparable to the rollover depths of nearshore sand clinoforms $(15-40 \mathrm{~m})$ off other steep, exposed coasts [Field and Roy, 1984; Hogarth et al., 2007]. The Surtla (Surtsey) edifice of Iceland provides a further analogue [Kokelaar and Durant, 1983]. That edifice grew by explosive eruptions producing a debris pile within only a few meters of sea level, which was then eroded by surf and currents to $45 \mathrm{~m}$ depth over the following 18 years. Divers observed a surficial sedimentary lag of volcanic blocks and gravel overlying sand. By analogy, the volcaniclastic debris of Azorean lava deltas is easily mobilized by surf, leaving a rugged, highly backscattering lag deposit formed of the remains of the delta subaerial lava, whereas the smooth foreset comprises redeposited clastics. As the grain sizes in nearshore deltas off Kilauea [Moore et al., 1973; Sansone and Smith, 2006; Tribble, 1991] and in subaerial outcrops [Furnes and Fridleifsson, 1974; Furnes and Stuart, 1976; Porebski and Gradzinski, 1990] are strongly varied, from poorly sorted sand to large blocks of lava, this explanation would imply movement of relatively coarse material down to $20-30 \mathrm{~m}$ depth during storms. Apart from one possible example (Figure S18), we have not observed evidence for lava mass flows (movement of lava while still fluid) inferred from subaerial outcrops [Bergh 


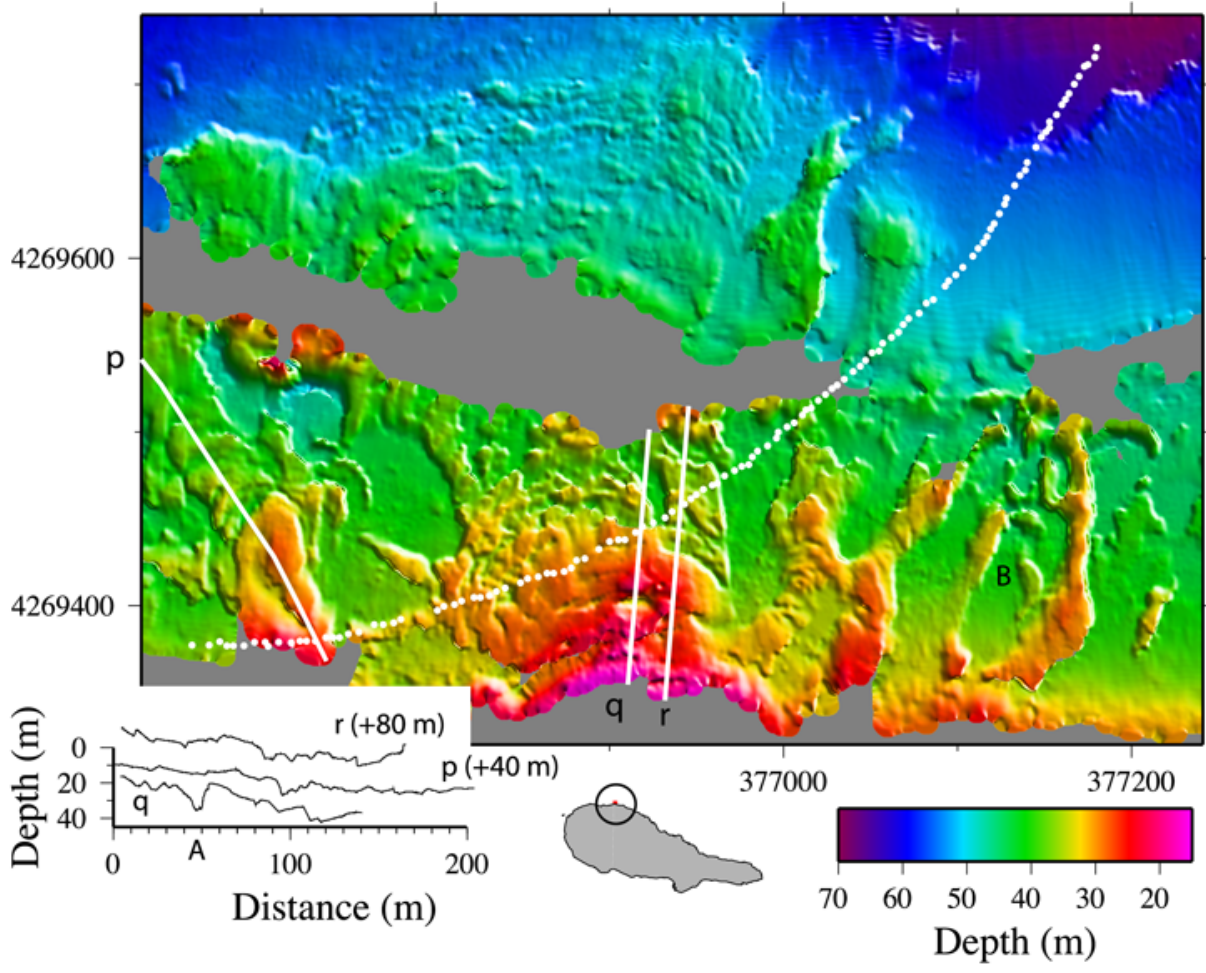

Figure 13. A 200-m-wide flow broken by deep surface fractures. Dotted line is the path of a boomer seismic profile revealing negligible sediment cover around the flow. Three cross sections $\mathrm{p}, \mathrm{q}$ and $\mathrm{r}$ are shown to the lower left. Further cross sections and grey shaded image are shown in Figure S13, which also shows the boomer seismic data.

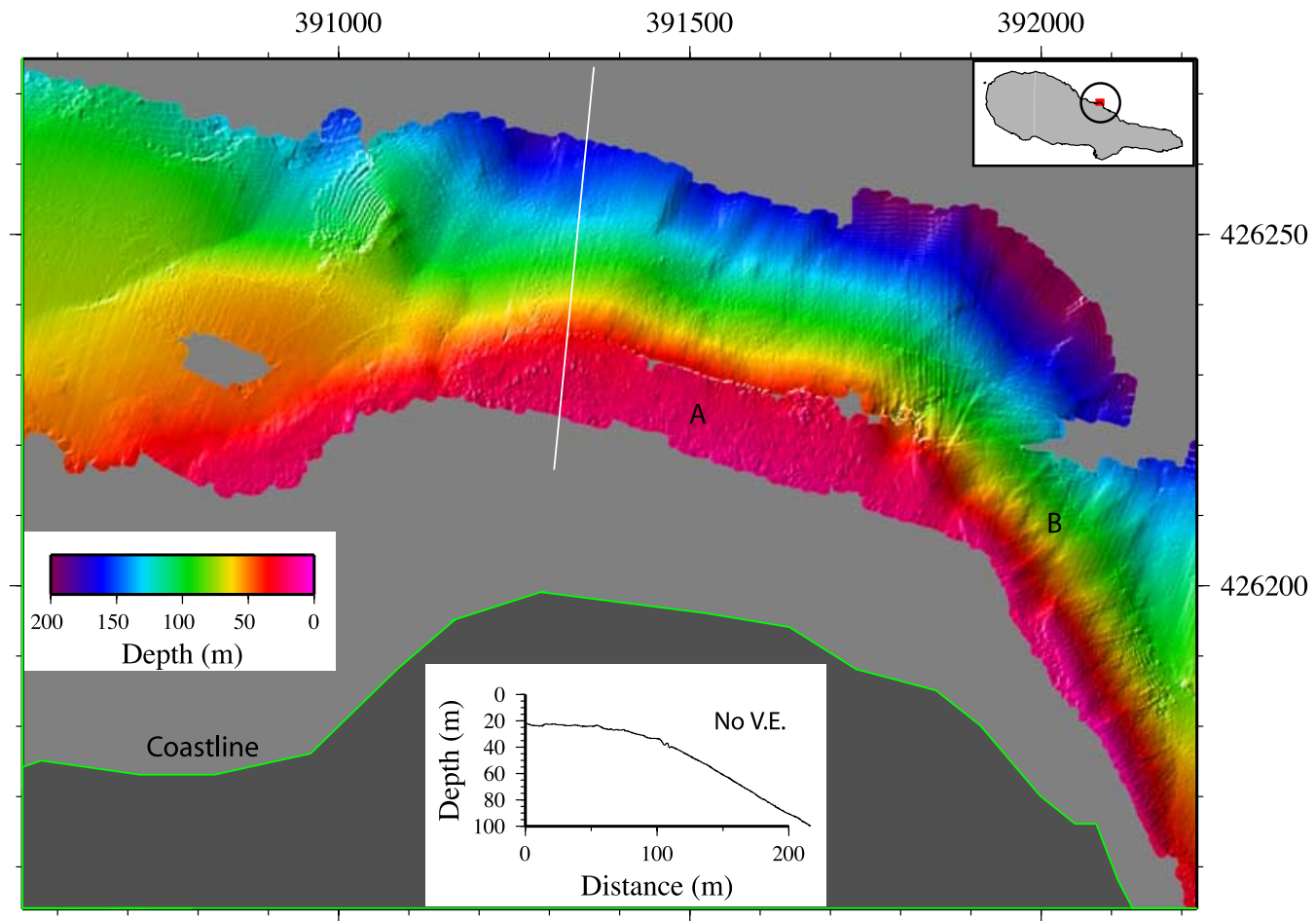

Figure 14. A shallow rocky coastal terrace with steep front lying near where the $1562-1564$ A.D. lava reached the shoreline. This type of feature is interpreted as an eroded lava delta. Cross section is shown with no vertical exaggeration. Further cross sections and grey shaded image are shown in Figure S14. 


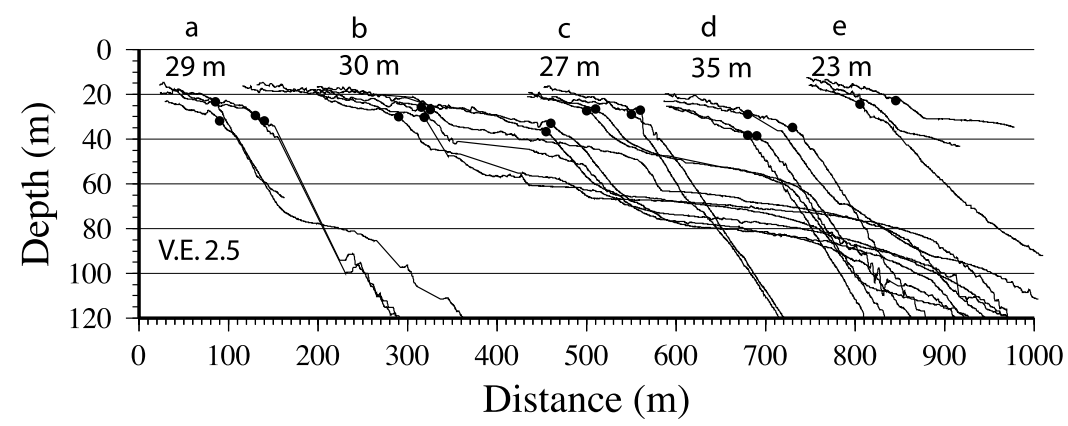

Figure 15. Sections across nearshore platforms interpreted as eroded lava deltas. The profiles are taken from Figures S2 (section a), S5 (section b), S14 (section c), S18 (section d), and S3 (section e).

and Gudmunder, 1991; Walker, 1992; White and Busby-Spera, 1987], although such features may be buried beneath the remobilized clastics.

[36] Figure 15 shows a selection of profiles across nearshore platforms around Pico. The small solid circles show interpreted breaks in slope, which have the average values given above each group of profiles. Although some deltas may be old and subsided with compaction or tectonics, the $1562-$ 1564 A.D. delta (profiles "c") is no different to the others. Platform depths therefore probably reflect the efficient erosion by ocean swell. No difference is detectable between either side of the island.

\subsection{Lava Flows Reaching the Shelf Edge}

[37] In Figure 11, two sets of flows approached the shelf edge and, at least in the northwesterly case ("B"), spilled down the slope. In Figure 16, a broad flow reached the shelf edge and spilled over (at "A"). Figure S1 shows two further examples. In Figure 2, shallow gullies lie downslope from these shelf edge flows. Although the connection is not strongly shown by the data, there is a potential for lava flows reaching the shelf edge to initiate sedimentary gravity flows, either because the lava itself moves rapidly on steep slopes and disintegrates [Bergh and Gudmunder, 1991] or because sediment deposits loaded by flows fail [Lodato et al., 2007]. These are additional mechanisms for eroding the flanks of volcanic islands besides hyperpycnal flows created during stream floods [Krastel et al., 2001], and sedimentary flows initiated by slope failures [Mitchell et al., 2003].

[38] Some lava flows may have passed coherently down the submarine slopes of the island but they are generally difficult to distinguish from ridge and

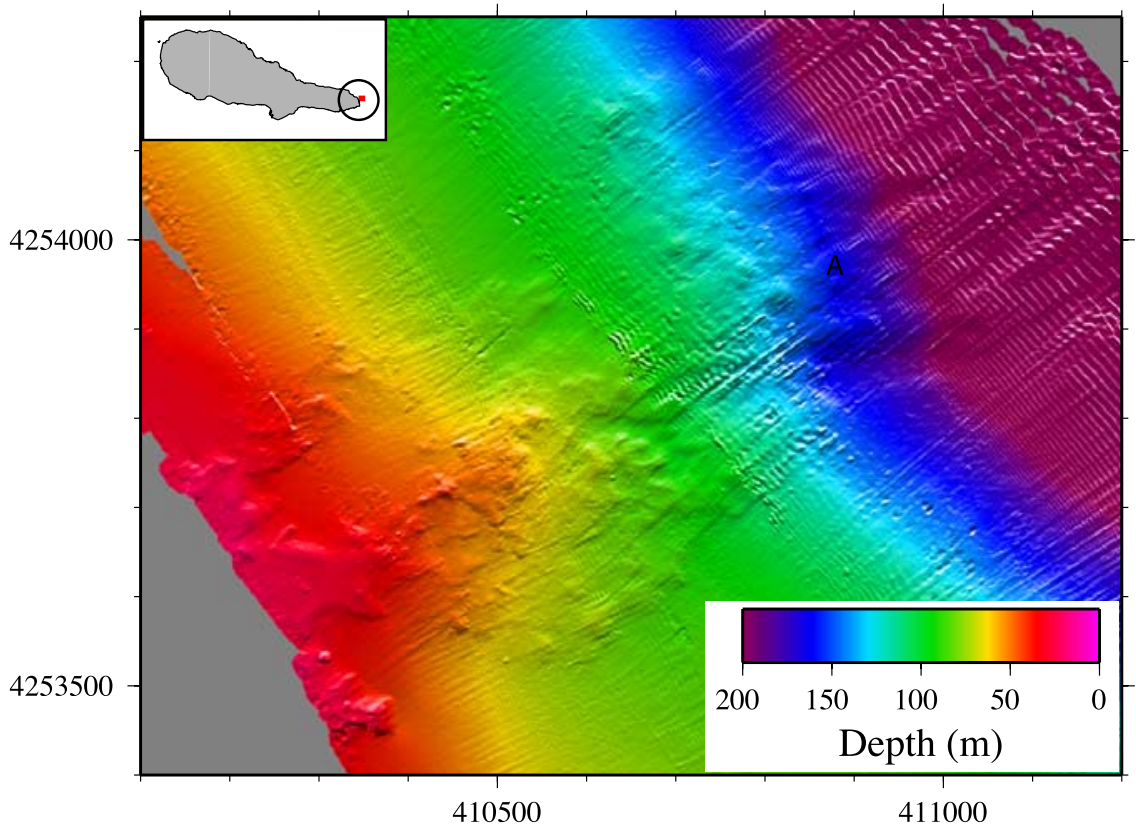

Figure 16. Flow reaching the shelf edge. Cross sections and grey shaded image are shown in Figure S16. 

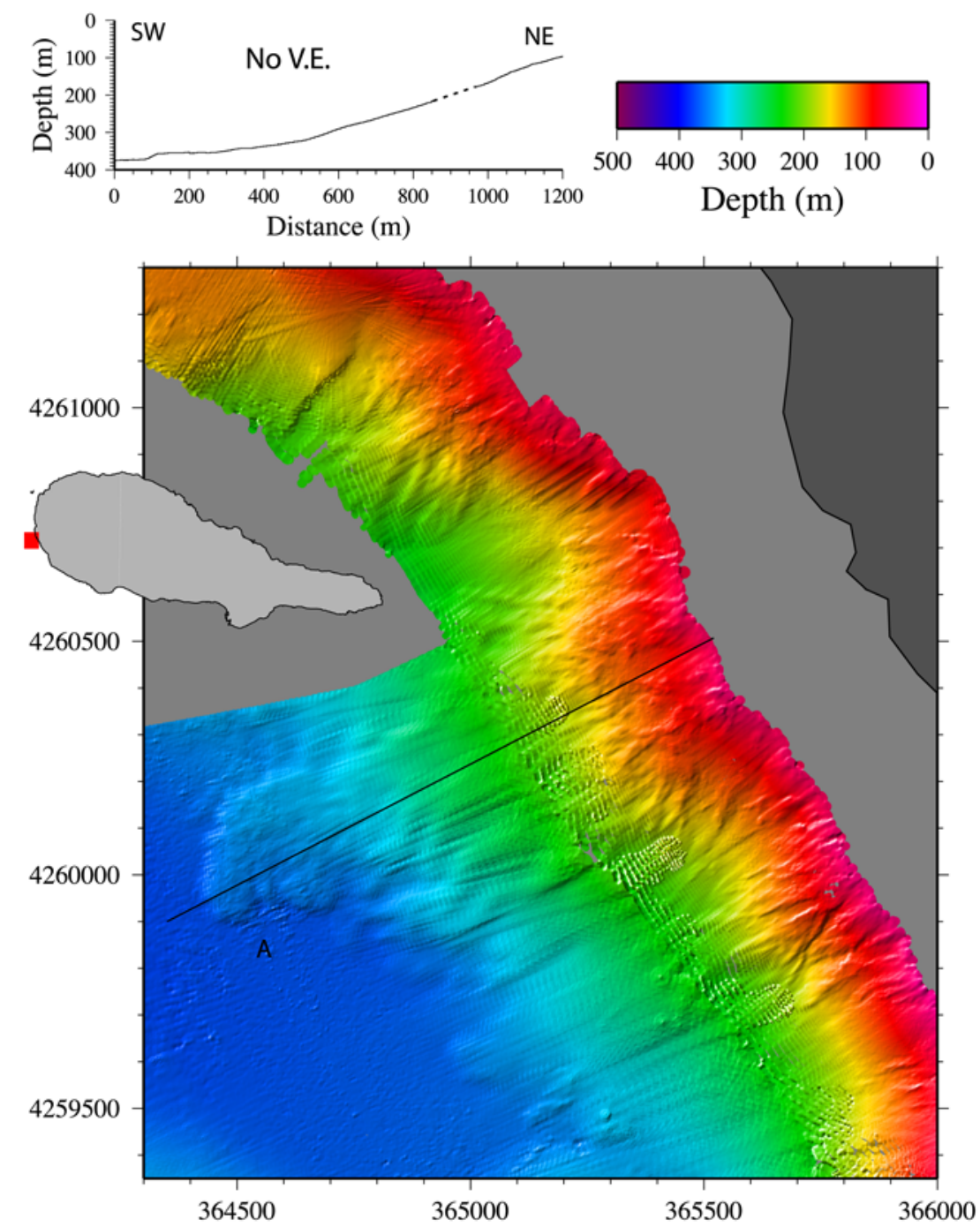

Figure 17. Flows traversing a $17^{\circ}$ slope to $380 \mathrm{~m}$ depth. A grey shaded image is shown in Figure S17.

gully erosional relief. Figure 17 shows flows southwest of Pico volcano that traversed a $17^{\circ}$ gradient and stopped on a platform near $400 \mathrm{~m}$ depth (at "A"). These flows are preserved because the gradient is shallower than the angle of repose at which fractured lavas readily disintegrate [Sansone and Smith, 2006].

\section{Coastal Retreat Rates and a Submarine Origin of These Lava Flow Structures}

[39] Rates of coastline retreat are fast around oceanic islands [Menard, 1986] because they are exposed to surf from ocean swell without the protection afforded by wide continental shelves that attenuate long-period swell reaching continental coasts [Masselink and Hughes, 2003]. Fast rates are suggested by observed strongly eroded coasts wherever our vessel passed historical lava and by the following horizontal coastline retreat data mostly from aerial photo analysis: median 0.2 to a peak of 1 $\mathrm{m} / \mathrm{a}$ on nearby São Miguel over 33 years [Borges, 2004; Borges et al., 1997], $18 \mathrm{~m}$ of young lava toes over 15 months on San Benedicto Island, Mexico [Richards, 1960], 25-37 m/a averaged over 8 years of the lava apron of Surtsey [Norrman, 1980; Sunamura, 1992], and $>100 \mathrm{~m}$ of a lava apron overlying pyroclastics of Capelinhos (nearby Faial Island) over 7 months [Machado et al., 1962].

[40] From Fairbanks [1989], sea level rose by typically $1 \mathrm{~m}$ per 100 years in the period of global warming following the Last Glacial Maximum. A given elevation would have been susceptible to surf erosion for around 200 years during the postglacial period of rapid sea level rise (allowing 
for tidal sea level fluctuation of $1 \mathrm{~m}$ and $1 \mathrm{~m}$ elevation range of surf force [Sunamura, 1992]). Multiplying Borges' [2004] coastal retreat rate of $0.2 \mathrm{~m} / \mathrm{a}$ by 200 years implies around $40 \mathrm{~m}$ of lateral retreat of rock surfaces on the shelf during the postglacial period. The rate of Borges' [2004] may be modest compared with the younger coasts mentioned above because the coasts they studied are somewhat sheltered by a shelf of finite width, although they may still be exaggerated compared with 200-year-averaged rates as a result of unsteadiness in geomorphic change [Gardner et al., 1987]. Nevertheless, $40 \mathrm{~m}$ is more than an order of magnitude larger than the meter scale of the fine structures observed in Figures 6-13. If the sea level curve of Fairbanks [1989] hides periods of more rapid sea level change, even greater coastal erosion would have occurred during the intervening periods of slow rise. Atlantic surf during winter storms around Surtsey were capable of quarrying meter-size blocks, lifting up to 5-t blocks $7 \mathrm{~m}$ vertically over cliffs and swash moving 2-t blocks $500 \mathrm{~m}$ seaward [Norrman, 1980].

[41] These nearshore lava structures therefore most likely formed during the Holocene period of elevated sea level and represent subaerial lava passed through sea level and spread onto the island's shelf or lava that has effused under water close to the shore, such as from tubes. The number of flow structures observed offshore can also be compared with the expected number from the average repose period of 130 years based on historic and prehistoric flows dated with $\mathrm{C}^{14}$ [Nunes, 1999]. If this event frequency persisted over the last 7,000 years of elevated sea level [Fairbanks, 1989], around 54 lava flows would have been emplaced. Quantitative comparisons are problematic as it is difficult to assign submarine flow structures to individual eruptions and not all erupted lava reached the coasts. Nevertheless, the new data are consistent with a significant proportion of 54 eruptions having sourced submarine flows.

\section{Fractal Analysis of Lava Flow Front Outlines}

[42] The fronts of subaerial 'a' a and pahoehoe lava flows are significantly different, pahoehoe fronts tending to be more convoluted and embayed. The advance of pahoehoe lava involves breakouts from seemingly random points within the flow leading to complicated branching [Baloga and Glaze, 2003; Crown and Baloga, 1999; Swanson, 1973], whereas rounded margins of 'a'a arise from lateral spreading of their fronts [Kilburn and Lopes, 1991]. The margins of basaltic lava have been found to be statistical fractals [Bruno et al., 1994, 1992; Gaonac'h et al., 1992; Luongo et al., 2000] and the fractal dimension D usefully discriminates between these two lava types (Figure 18a) [Bruno et al., 1992].

[43] Margins of submarine flows were characterized for comparison. Owing to incomplete seabed coverage by the sonar and partial censoring by sediment deposits, flow outlines can be difficult to identify but four fronts least affected by these problems were digitized (Figures 6, 9, 11, and S19, digitized as shown in Figure S22). Their fractal dimensions were determined using the ruler stepping method. Following Bruno et al. [1994], rulers of successively greater length, increased logarithmically, were used until a minimum of 5 steps traced the boundary. Stepping was then carried out in the reverse directions along boundaries and the two cumulative distances averaged. Plots of the cumulative stepped distance versus ruler length shown in Figure 18b ("Richardson" plots after Richardson [1961]) reveal fractal-like behavior (power law trends) for ruler lengths beyond a roll-over of $\sim 10 \mathrm{~m}$, which is roughly our estimated digitizing resolution and similar to the size of individual flow fingers.

[44] Least squares regressions of $\log _{10}$ (perimeter) on $\log _{10}$ (ruler length) were calculated for ruler lengths $>10 \mathrm{~m}$. Fractal dimensions D are derived from the power law gradients of such plots, which equal 1-D [Turcotte, 1997]. The values for $\mathrm{D}$ found here vary from 1.17 to 1.24 with a mean of 1.22 (excluding S6a center). Although transition from 'a'a to pahoehoe lavas is possible with declining shear rate and in breakouts [Duncan et al., 2004; Hon et al., 2003], and some were recorded in the ROV images, these flows are most likely to have been 'a'a by the time they reached the coasts, distant from eruption sites lying more centrally in the island [Nunes, 1999]. As mentioned earlier, the northerly 1718 flow adjacent to Figure 6 was 'a'a subaerially. However, D values (vertical arrows in Figure 18a) are all larger than those of typical 'a'a and more like those of pahoehoe lavas.

\section{Discussion}

[45] The sonar data reveal many lava structures on the shelf, with a variety of morphologies. We now suggest some possible explanations for the features 

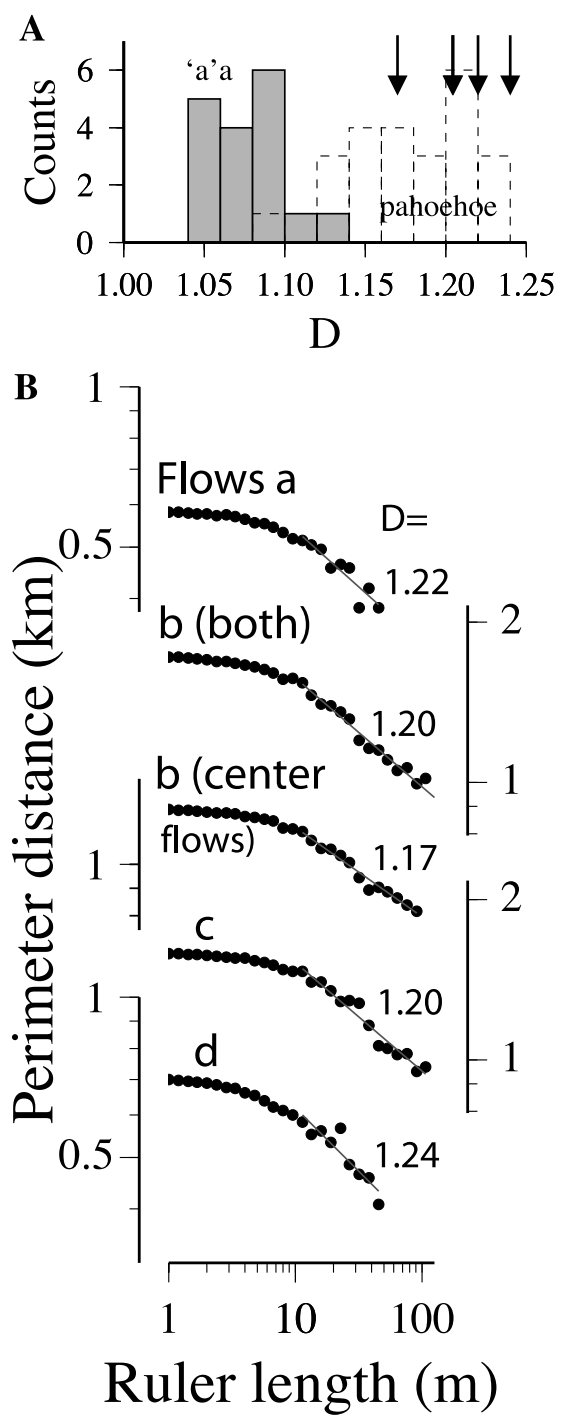

Figure 18. (a) Histogram of fractal dimensions of ' $a$ 'a and pahoehoe flow fronts [Bruno et al., 1994] along with values (arrows) derived in Figure 18b. (b) Richardson plots for four submarine flow fronts shown in Figure S22 together with (red lines) least squares regressions of $\log _{10}$ (perimeter) on $\log _{10}$ (ruler length). The fractal dimensions $\mathrm{D}$ implied by these regressions are shown to the right of each graph. Flows "a", "b", etc., on the left refer to flows in Figure S22. Two graphs for S6 were calculated, one including only the center flows and one including both center and east flows.

observed, drawing on the limited knowledge available on nearshore flows from the literature.

\subsection{Flow Extents}

[46] Whereas some flows reached the shelf edge, most terminated on the shelf. This could partly represent a fortuitous association; basaltic lava flow lengths compiled by Walker [1973] have a median value of $4.1 \mathrm{~km}$ and $80 \%$ of the flows were shorter than $10 \mathrm{~km}$, comparable to the distance from Pico caldera to the coasts. In Pinkerton and Wilson's [1994] extension of Walker's analysis, flow lengths of Hawaiian lavas were found primarily to depend on effusion rates, secondly on gradient and thirdly, though less well constrained, on rheological properties. Given how widely average effusion rates vary on individual volcanoes (e.g., by 2 orders of magnitude on Etna [Walker, 1974]) and that magma discharge in individual eruptions declines irregularly with time [Wadge, 1981], flow lengths are unlikely to be abruptly limited by effusion. Lava is instead suggested to stop moving because of reduced driving stress owing to increased buoyancy and cooling-induced viscosity in water. Over the Quaternary, this may have limited the lateral growth of the edifice, because sea level has been at the island shelf edge only during brief periods of glacial maxima and water over the shelf otherwise regulated the maximum extent of flows. For significant prograding of the submarine flank of a volcanic island to occur, volcanic output probably needs to be sufficiently large that the shelf is effectively eliminated such as on the southern flanks of Pico and Kilauea.

\subsection{Cooling of Submarine Flows}

[47] Although lava is expected to cool faster in water than in air, there have been no instrumented observations of active submarine flows and consequently the theory is underdeveloped. In cinematic film of growing pillow lavas, incandescence of surface breaks typically lasted $\sim 5$ seconds s, suggesting initial surface cooling rates 10 times faster than in air [Moore, 1975]. Convection probably carries heat away from lava surfaces by 2 orders of magnitude faster in water than in air because of water's greater heat capacity [Griffiths, 2000]. However, cooling rates of thicker lava bodies are less clear [Clague et al., 2000; Shaw and Moore, 1988]. Once the flow surface cools near to ambient temperatures, if the flow interior were to cool by vertical conduction alone, it could remain above its liquidus temperature $\left(800^{\circ} \mathrm{C}\right)$ for more than a year, based on temperature measurements [Peck et al., 1977] of a lava lake of comparable thickness (15 m) to the vertical relief of these coastal flows and rates of crustal thickening [Hon et al., 1994]. (Lava convection should be minor because of finite yield strengths in distal flows where crystal contents are high as here [Nunes, 1999] from cooling and gas loss [Pinkerton and Norton, 1995; Sparks and 
Pinkerton, 1978].) Historical reports, in contrast, suggest the northerly 1718 flow was emplaced in only days or weeks [Nunes, 1999].

[48] Cooling of lava lakes is enhanced by convection of rainwater and steam through fractures, a process that in one example enhanced cooling by $\sim 5$ times based on modeling [Peck et al., 1977]. As fractures are created by cooling-induced contraction, the fluid circulation and fracturing are coupled [Shaw and Moore, 1988], leading to cyclic bands in columnar joints [DeGraff and Aydin, 1987]. For these submarine flows (in depths $<100 \mathrm{~m}$ ), pressures are insufficient to prevent steam forming, so the problem is broadly similar to the lava lakes cooled by rainwater. Cooling should be faster because submarine lava is continually immersed and cracks can be opened dynamically during flow, such as where the lava passes over nonuniform underlying topography or from varying flow speed. At 'a'a flow fronts, the caterpillar-like movement of the crust carried forward and under the flow as it advances viscously forces open fractures [e.g., Dragoni et al., 2005; Stasiuk et al., 1993]. Therefore, although some fingers emplaced by sliding on steep gradients [Sansone et al., 1990; Sansone and Smith, 2006; Tepley and Moore, 1974] may be controlled by lava supply, flow fronts are sites of preferentially rapid cooling, potentially explaining how individual flow bodies become arrested. In contrast, deep water flows are not so limited because high ambient pressure prevents exsolution and thus lavas have low viscosity [Gregg and Fornari, 1998].

[49] In analytical models of submarine flows, cooling within the flow body has been assumed to occur purely by conduction, ignoring these pore fluid effects [Gregg and Chadwick, 1996; Gregg and Fink, 1995; Griffiths and Fink, 1992; Klingelhöfer et al., 1999; Umino et al., 2000, 2002; Zhu et al., 2002]. Laboratory experiments with polyethylene glycol wax [Gregg and Fink, 1995] may also not replicate the effect of cooling through surface cracks particularly well. The experimental results suggested that lava morphology should be affected by flow-wise gradient, with the abundance of pillows declining relative to sheet flows with steepening gradient [Gregg and Fink, 1995]. Gregg and Smith [2003] found instead pillows to be similarly common in the field on all gradients and sheet flows rare on steep gradients. They suggested that the problem lay in cooled surface wax in the experiments having a higher effective tensile strength than solid lava crust.
Indeed natural seabed pillows [e.g., Fornari et al., 1980] are more rounded and less blocky than the experimental pillows [Gregg and Fink, 1995; Griffiths, 2000], suggesting that their shapes are instead controlled by a near-surface elastic-like layer opposing internal pressure [Walker, 1992] rather than a more solid crust.

[50] We suggest that the branching morphologies of these coastal flows can be explained by irregularities in the strong viscoelastic layer, lying between the outer brittle crust (which is typically weakened by fractures [Hon et al., 1994]) and the liquid core of the flow, which opposes flow inflation. According to Hon et al. [1994], the outer lava is viscoelastic between $800^{\circ} \mathrm{C}$ and $1070^{\circ} \mathrm{C}$. By analogy with lava lakes cooled by rainwater [Peck et al., 1977], underwater the penetrating pore water cooling front beneath cracks compresses the temperature profile, making the viscoelastic layer narrower and weaker. Cooling along cracks should compress the outer viscoelastic layer in a strongly irregular manner, depending on where cracks are open and how persistently, leading to irregularly located breakouts from the still-liquid flow. This in turn leads to the pahoehoe-like fractal dimensions of these dendritic flows, advancing by repeated break-out, emplacement of lobes and inflation beneath a viscoelastic layer like pahoehoe [Baloga and Glaze, 2003; Crown and Baloga, 1999; Gregg and Keszthelyi, 2004]. Some aspects of pillow lava growth sequences [Sansone et al., 1990; Sansone and Smith, 2006; Tepley and Moore, 1974] may also be explainable by variability of a viscoelastic layer. Parts of the films show pillows suddenly breaking out where cracks had been exhaling bubbles. Such features could be interpreted as enhanced cooling along the cracks having left the underlying viscoelastic layer thin and weak, allowing breakouts to occur at those points (Figure 19). Heterogeneous heat loss therefore needs to be considered in numerical and laboratory modeling of submarine lavas.

\subsection{Lava Buoyancy in Water}

[51] Although buoyancy effects are likely to be subordinate to other factors influencing flow under water such as rheology [Gregg and Fornari, 1998] and gas pockets decoupling flow from boundaries [Soule et al., 2006], an abrupt change in the density contrast driving flow occurs at the water line. The potential effect is illustrated by a simple model assuming a Newtonian lava rheology and equilibrium conditions. If the contrast of the lava density 


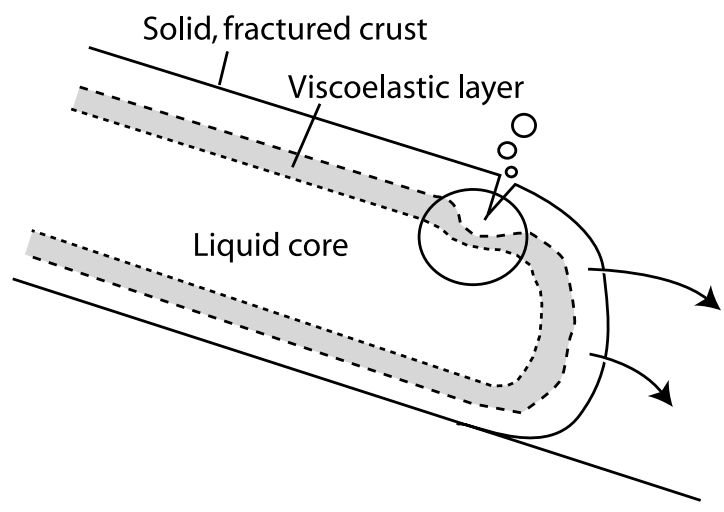

Figure 19. Schematic interpretation of pillow growth sequence in which viscoelastic layer beneath crack exhaling bubbles (circled) is thinned by enhanced cooling and thus weakened, leading to the pillow crust becoming vulnerable to breakout (curved arrows). Interpretation based on cinematic film sequences [Sansone et al., 1990; Tepley and Moore, 1974]. Proportions of layers are exaggerated.

with its ambient fluid is $\rho-\rho_{\mathrm{a}}\left(\mathrm{kg} / \mathrm{m}^{3}\right)$, the Jeffreys [1925] equation for purely viscous flow suggests that the specific flux Q $\left(\mathrm{m}^{2} / \mathrm{s}\right)$ of lava of viscosity $\mu$ (Pa s) and thickness $\mathrm{h}(\mathrm{m})$ down a gradient $\alpha$ is [Turcotte and Schubert, 1982]

$$
Q=\frac{\left(\rho-\rho_{a}\right) g \sin (\alpha) h^{3}}{3 \mu}
$$

where $g$ is the acceleration due to gravity $\left(\mathrm{m} / \mathrm{s}^{2}\right)$. Equating the fluxes above and below water level (i.e., assuming continuity), that the flow occurs on a uniform gradient and its viscosity remains constant, the change in flow thickness would be

$$
\frac{h_{w}}{h_{a}}=\sqrt{[3]} \frac{\rho}{\rho-\rho_{w}}
$$

where $\rho_{\mathrm{w}}$ is seawater density $\left(1.03 \mathrm{~g} / \mathrm{cm}^{3}\right)$ and air density is negligible. A typical unvesiculated basaltic liquid density is $2.7 \mathrm{~g} / \mathrm{cm}^{3}$ [Stolper and Walker, 1980]. For an extreme lava vesicularity of $50 \%$, its density $\rho=1.35 \mathrm{~g} / \mathrm{cm}^{3}$, suggesting that $\mathrm{h}_{\mathrm{w}} / \mathrm{h}_{\mathrm{a}}=1.6$, i.e., the lava would slow and thicken by $60 \%$. At the opposite extreme of $0 \%$ vesicularity, a lava density of $\rho=2.7 \mathrm{~g} / \mathrm{cm}^{3}$ implies $\mathrm{h}_{\mathrm{w}} / \mathrm{h}_{\mathrm{a}}=$ 1.17. Although no systematic vesicularity data are available for Pico, the median of reported vesicularity values for the subaerial section of the Hawaii Scientific Drilling Program at Hilo [Moore, 2001] (distal flows of Moana Loa and Moana Kea) is $13 \%$, so buoyancy effects may typically lie toward the modest end of these two extremes. Because postemplacement inflation can easily modify thicknesses by larger amounts than these values, such modest thickness variations may need observations of flowing lava to detect. How buoyancy affects flow behavior in detail may also depend on other factors: Typically, the nearshore bathymetry is not uniform in gradient, if strongly fractured vesicles could be flooded with water, and the above argument ignores lava yield stress and assumes equilibrium conditions.

[52] Nevertheless, the abrupt waterline change in buoyancy could help to explain compression features such as outlined in section 5.4 and contributes to slowing flows beneath water. The effect of buoyancy is also likely to change with further water depth because vesicles in fluid lava are closed by ambient pressure. According to Moore's interpretation of recovered seabed samples [Moore and Clague, 1987; Moore et al., 1985], subaerial lava from Mauna Loa with original vesicle contents of $25-50 \%$ compressed as they traveled below sea level somewhat faster than expected from Boyle's law because of partial resorption of volatiles. Vesicle volumes reduced to less than a few percent by $100 \mathrm{~m}$ depth. Figure 20 shows the change in density contrast of lava of various original vesicularities for a magma density of $2.7 \mathrm{~g} / \mathrm{cm}^{3}$, predicted assuming gas contracts perfectly according to Boyle's law. If the lava were originally $50 \%$ vesicles, its submergence would lead initially to its density contrast halving in very shallow water

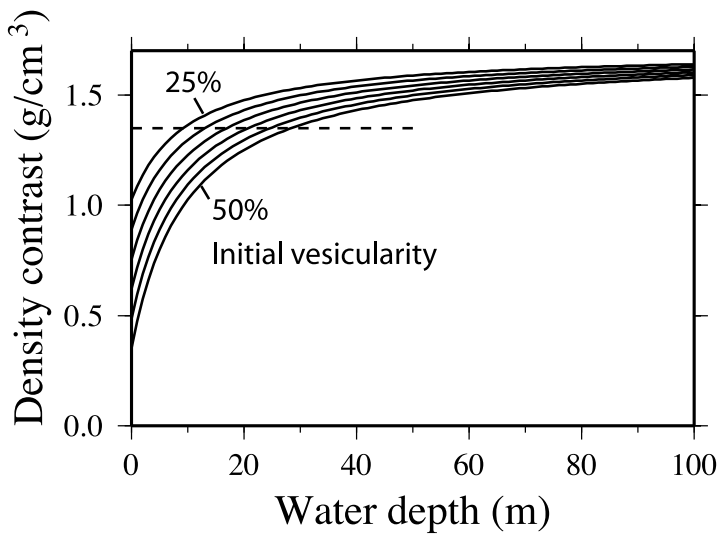

Figure 20. Change in density contrast of lava in water with increasing hydrostatic pressure (water depth) caused by compression of vesicules following Boyle's law. Different curves give the response expected for initial (subaerial) vesicularities of $25 \%$ to $50 \%$ in steps of $5 \%$. An unvesiculated lava density of $2.7 \mathrm{~g} / \mathrm{cm}^{3}$ was assumed. Horizontal dashed line is the density of a lava in air with $50 \%$ vesicularity. 
but then almost a doubling from that value with increasing depth and ambient pressure toward midshelf depths. By $40 \mathrm{~m}$ it would have the same density contrast as it had subaerially (dashed line at $1.35 \mathrm{~g} / \mathrm{cm}^{3}$ in Figure 20). For a $25 \%$ vesicularity lava, half the difference in density contrast is recovered. Depending on the active flow's thickness and gradient, the net effect should be reduced driving stress, which augments the effects of cooling on rheology in slowing flows compared with subaerial flows. The effect would be greatest near the water level, before ambient pressure closes vesicles. Vesicle closure also affects lava bulk viscosity, but whether it increases or decreases and by how much depends on a number of factors such as volatile species resorbed, initial vesicularity and strain rates [Spera, 2003], which are all unknown here. Density contrast can be reduced at water level by a similar fraction to the gravitational acceleration on Mars $(0.4 \mathrm{~g})$ relative to Earth. If pahoehoe lava were erupted under similar conditions to an Earth pahoehoe lava, Keszthelyi et al. [2000] suggested that it should be thicker and slower moving.

\subsection{Transverse Clefts}

[53] The transverse clefts in Figures 6, 8, and 13 are reminiscent of surface creases and fractures in more silica-rich flows [Anderson and Fink, 1992; Clynne et al., 2000]. Lescinsky and Merle [2005] produced similar features in laboratory wax experiments with declining effusion rate. Fractures and platelets have also been observed in basaltic lava flows, e.g., in the Laki rubbly pahoehoe [Guilbaud et al., 2005].

[54] These features most likely formed by extension of a brittle upper lava surface [Lescinsky and Merle, 2005]. A second explanation, that they formed by extension of the whole flow mobilized by fluidization of underlying sediment, is considered unlikely because boomer seismic data along the dotted path in Figure 13 around one extended flow reveal little sediment cover (Figure S13d). The rapid cooling expected with whole flow extension would also be difficult to reconcile with the flow then apparently sourcing the branches appearing in Figures 6 and 8. As the surface features are remarkably angular and deep, a further explanation that they represent individual flow advance fronts seems unlikely also.

[55] Their plan view convexity in the direction of flow is remarkable; tensional fractures are more typically concave downflow in lavas [Kilburn,
1990] and in other kinds of extending cohesive mass movements [Varnes, 1978], arising from how shearing margins rotate the principal stress axes. In contrast, ogives (pressure ridges formed by flow convergence) are convex downflow [de Silva et al., 1994]. We therefore suggest that the lava surface was preconditioned during a phase of convergence, such as where flows slow below cliffs or as a result of the buoyancy change in water (section 8.3). Extension then occurred, with fractures controlled geometrically by the folds, as the more distal lava continued. Kilburn [1990] similarly interpreted smaller convex downflow fractures as controlled by ropes formed earlier in pahoehoe surfaces.

\subsection{Pressurization}

[56] Several flows apparently moved onto the shelf as large bodies, stopped, and then sourced smaller lobes or toes, a sequence of emplacement and breakouts analogous to that of subaerial flows [Pinkerton and Sparks, 1976]. For example, in Figure 6, the central flows form a smooth elongate mass that ends abruptly, leaving a change of gradient at "B". Beyond that edge lie at least two elongate lobes trending $\mathrm{N} 010^{\circ} \mathrm{E}$. From various points along those lobes and other smaller ones, a series of smaller lobes extends laterally forming a halo around each elongate lobe. The easterly flows in Figure 6 ("C") also suggest massive emplacement followed by breakouts, leading to growth of the dendritic-like toes. A two stage development can similarly be inferred for the flow in Figure 8. In Figure 10, the tumuli imply that the flow interior pressurized to elevate the lava crust. A breakout then led to the easterly channel developing. The submarine flow thicknesses around Pico of 5-20 m overlap with 'a'a thicknesses of similar gradients compiled by Kilburn [2004, Figure 5] but appear significantly thicker on average, consistent with inflation. "Bread crust" textured surfaces of the 1969 Kilauea lava flow observed underwater [Moore et al., 1973] and abundant tumuli in lakeentering lavas in Japan [Obata and Umino, 1999] also imply pressurization in comparable situations.

[57] The observations prompt the following conceptual model. The flows stopped on the shelf because of the lava effusion rate declining toward the ends of eruptions, flow front cooling or from buoyancy. As a crust grew from surface cooling and viscous stresses dissipated, the lava interior accumulated pressure from the magmastatic head associated with the upstream elevation change over coastal cliffs and nearshore shelf gradients. A 
maximum pressure can be estimated by assuming zero vesicularity and that all viscous flow stresses dissipated. For example, $2.7 \mathrm{~g} / \mathrm{cm}^{3}$ lava density implies $0.27 \mathrm{MPa}$ accumulated from a 10-m-high cliff and $0.17 \mathrm{MPa}$ from each $10 \mathrm{~m}$ of depth change below sea level (allowing for buoyancy), thus accumulating to $>1 \mathrm{MPa}$ by the $50 \mathrm{~m}$ depths of the tumuli in Figure 10 and by the $60 \mathrm{~m}$ depths of the flow fronts of Figures 6 and 8. If initial (subaerial) vesicularity were as high as $50 \%$ and the vesicles compressed with Boyle's law, the 0$60 \mathrm{~m}$ depth-averaged density contrast would be $1.17 \mathrm{~g} / \mathrm{cm}^{3}$ (calculated from Figure 20). Such a value implies around $0.7 \mathrm{MPa}$ overpressure could accumulate from sea level to $60 \mathrm{~m}$ depth.

[58] When a tumulus inflates, its interior pressure opposes the strength of the viscoelastic layer [Hon et al., 1994]. Cashman and Kauahikaua [1997] interpreted reduced vesicularity of an inflated flow on Kilauea as due to this overpressure, which they calculated as 0.2 MPa. From section 8.2, underwater the penetrating pore water cooling front compresses the temperature profile and the viscoelastic layer should be weaker, so $0.2 \mathrm{MPa}$ is an upper bound for submarine flows. Allowing for the 10$20 \mathrm{~m}$ heights of the tumuli in Figure 10, which imply a further $0.2-0.3 \mathrm{MPa}$ needed to lift passively the lava surface, the $0.7-1.0 \mathrm{MPa}$ static pressure from lava passing from sea level to the tumuli bases is easily sufficient to explain inflation. More difficult to explain is why only these two tumuli are recorded in the data set. Possibly this results from the sonar data collected being generally farther from steep topography than the two examples in Figure 10.

\subsection{Incidence of Flows and Deltas}

[59] According to Peterson [1976], Hawaiian deltas are formed largely of moderately or slowly emplaced pahoehoe lava, whereas [Moore et al., 1973] notes that the 1969 submarine 'a'a flow was probably viscous. Although more detailed comparisons of onshore and offshore flow morphologies are needed, the northerly 1718 flow ('a'a at the coast) lies adjacent to the dendritic flows in Figure 6, whereas the 1562 flow field (pahoehoe at the coast) formed a lava delta, apparently corroborating Moore et al.'s [1973] suggestion.

[60] This also raises the question as to whether, if composition were an important indicator of erupted lava temperature and viscosity, the Pico submarine flows and lava deltas correspond with more and less evolved lavas, respectively. Some rock sam- ples associated with nearshore features using a detailed geological map [Nunes, 1999] are marked by small colored circles in Figure 4 . The numbers in Figure 4 identify the data figures, with italics representing where they show deltas and normal font the lava flows (Figure S1i shows flows emanating from a delta, i.e., both types occur). From these few data, there appears to be no strong association of flow or delta with composition, supporting the view that other factors such as viscosity, local topography, flow thickness and magma flux play greater roles in whether flows penetrate sea level or form deltas.

\subsection{Implications for the Submarine Geological Evolution of Volcanic Islands}

[61] During times of falling sea level, surf remobilizes shelf sediment and volcanic material to the island's submarine slope. With the shelf exposed subaerially, lava can more easily reach the shelf edge, so space created by erosion becomes filled with lava, by an amount depending on volcanic effusion, mobility and shelf geometry. Carracedo et al. [1999] considered also the role of differing resistance to erosion by surf, suggesting that hyaloclastite and other volcaniclastic debris should be more easily eroded than subaerially erupted lava. A complex stratigraphy of lava and sediment under the shelves of subsiding islands is therefore possible. Indeed, drilling through the rapidly subsiding coast of Mauna Loa revealed a sequence of lava deltas and shelf sediments, reflecting competing volcanic supply and subsidence [Lipman and Moore, 1996], including one submarine-emplaced flow [Moore et al., 1996].

[62] The implications of these sonar results for the more deeply submerged compositions of islands are more equivocal. Although most flows recorded here terminated on the shelf, there are examples of lava flowing to the shelf edge. Large areas of the slopes are smooth, as expected if they largely comprise volcaniclastic debris [Moore and Chadwick, 1995], but elongate flows on the slope would be difficult to distinguish in the more ruggedly gullied areas. Furthermore, lava on the steep slopes around Kilauea disintegrates rapidly with time leaving a rubble [Sansone and Smith, 2006], a process that likely occurs generally as the uppermost slope gradients (Figure 5) equal the angle of repose of talus [Mitchell et al., 2000]. The clearest example of a slope-traversing flow (Figure 17) is preserved because it has a shallower gradient $\left(17^{\circ}\right)$. Calculating how much clastic and 
volcanic material has accumulated on the shelf over the Holocene may help to assess how much material remobilizes to the submarine slopes during falling sea level and hence indicate its potential volumetric importance to the slopes. In the scientific drilling of Hawai' $i$, massive flows in the upper submarine unit, representing the upper slope of the island, were on average $3 \mathrm{~m}$ thick and typically formed 5-20\% of the section [Garcia et al., 2007]. On the basis of degassed $\mathrm{S}$ and low vesicularities, they were interpreted as large subaerial flows that had traversed the shelf and submarine slope, suggesting a significant contribution to the island's slope, though still secondary to hyaloclastite which formed the majority. A comparable mixture of flows and hyaloclastite would not be unsurprising also for Pico based on the sonar data collected here.

\section{Conclusions}

[63] These new multibeam sonar data showing submarine-emplaced lava flows, and boomer data showing abundant sediment (Figure 2, bottom right inset) [Quartau et al., 2003], reveal that the shelves of volcanic ocean islands can be highly active geologically. Lava flows have strongly crenulated fronts. Some are dendritic, arising from the flow front repeatedly becoming arrested and new fingers or lobes produced by breakouts. Fractal dimensions of four flows (mean $\mathrm{D}=1.22$ ) are all larger than those of subaerial 'a' a fronts and more like those of subaerial pahoehoe, as a result of branching. Evidence for flow pressurization after emplacement includes these breakout sequences, thicknesses greater than typical subaerial flows, tumuli and longitudinal creases. Transverse clefts occur in some flows, where fluid interiors have extended brittle carapaces, but curiously the clefts occur in arcs convex downflow rather than concave downflow as would be expected from shear along lateral boundaries. Other features include eroded lava deltas forming flat-topped terraces, flows with surface folds and lava channels. Whereas the 1516 eruption left a pahoehoe lava field at the coast forming a lava delta, the 1718 eruption was an 'a'a type and may have penetrated below sea level to generate the dendritic flow structures observed offshore. However, more study is needed to determine if 'a' a lava is generally more capable of offshore penetration than pahoehoe.

[64] Lava is expected to cool more rapidly underwater than subaerially, but theory in this area suffers from a lack of in situ instrumented observations. Although, initial surface cooling is rapid because of the large heat capacity of water, cooling of the lava interior is not necessarily rapid if it occurs merely by conduction. By analogy with the enhanced cooling of lava lakes by rainwater penetrating cracks, actively flowing coastal submarine lava flows are probably strongly cooled by fluids penetrating surface fractures. Where flows move in a caterpillar-like fashion, fractures are dynamically opened at flow fronts so cooling is enhanced there, potentially explaining how flow fronts become arrested. Furthermore, rapid cooling by pore fluids will compress the conductively controlled viscoelastic layer, thus weakening it and making the flow vulnerable to breakouts. Irregular locations of cracks causing irregular weakening of the viscoelastic layer potentially explains the pahoehoe-like fractal dimensions of these flow fronts and breakouts from cracks in pillow lava sequences also. We suggest therefore that improvements in modeling submarine flows need to consider irregular cooling through surface fractures.

[65] On initial submergence, the buoyancy of lava with its surroundings also abruptly increases, decreasing its density contrast with its surroundings by up to half for an extreme $50 \%$ vesicularity lava. If all other factors are uniform, the associated reduction in local driving stress at the water line may encourage the lava to back up and compress, potentially explaining some ogive-like folds observed offshore. Folds thus created, or acquired in subaerial development of the flow, may subsequently control the pattern of deformation when the crust extends to leave the downflow convex clefts. With increasing water depth and ambient pressure, vesicles close and much of the density contrast can be recovered again (completely for initially $50 \%$ vesicularity lava but less for smaller vesicularities).

\section{Acknowledgments}

[66] The greatest thanks are due to the crew and marine biologists of the University of the Azores "DOP" who helped install the sonar and contributed to watch standing and making a very enjoyable field experience (special thanks to Eduardo Isidro and Frederico Cardigos and to João Figueiredo of the Department of Geosciences). Thierry Schmitt was invaluable in helping the setup and first week of survey. We thank Karsten Haase for kindly providing sample material for the major element analyses. We thank the following agencies for funding: the Royal Society, the British Council, the Higher Education Funding Council for Wales, the Regional Directorate for Science and Technology of the Azores and Portuguese projects MARINOVA and MAROV (PDCTM/P/MAR/15249/ 1999). C.B. was funded by a postdoctoral fellowship of the 
Max Planck Society and by the Deutsche Forschungsgemeinschaft (grant HA2568/9-3) and N.C.M. was funded by a research fellowship of the Royal Society. F.T. has been financed by a Ph.D. grant (ref SFRH/BD/12885/2003) from the Fundação para a Ciência e a Tecnologia. João Carlos Nunes of the University of the Azores is acknowledged with thanks for logistical advice and for providing a copy of his $\mathrm{Ph} . \mathrm{D}$. thesis. The boomer seismic data were collected with funding from the regional authority of the Azores. The NERC GPS pool lent a back-up kinematic GPS unit. Pietro Basciano of Thales Geosolutions Italy is thanked for advice on mounting the sonar. Thanks are due to Russell Dodd of GSE Rentals Ltd. for assistance with the equipment installation, the Portuguese Hidrographic Institute for installation of a tide gauge and Bernie Coakley for advice on the installation design. The first author also acknowledges helpful discussions with researchers at the University of Hawaii, including Mike Garcia, Scott Rowland, Andy Harris, Bruce Applegate, John Smith, and John Sinton and with Dave Pyle. A special thanks to Harry Pinkerton (Lancaster) and journal reviewers Jess Trofimovs and Jim Kauahikaua whose comments on the paper significantly improved it.

\section{References}

Anderson, S. W., and J. H. Fink (1992), Crease structures: Indicators of emplacement rates and surface stress regimes of lava flows, Geol. Soc. Am. Bull., 104, 615-625.

Anderson, T. (1910), The volcano of Matavanu in Savail, Q. J. Geol. Soc. London, 66, 621-639.

Applegate, B., and R. W. Embley (1992), Submarine tumuli and inflated tube-fed lava flows on Axial Volcano, Juan-deFuca Ridge, Bull. Volcanol., 54, 447-458.

Arculus, R. J. (1973), Recent submarine pillow lavas in the Catania area, eastern Sicily, Philos. Trans. R. Soc. London, Ser. A, 274, 153-162.

Baloga, S. M., and L. S. Glaze (2003), Pahoehoe transport as a correlated random walk, J. Geophys. Res., 108(B1), 2031, doi:10.1029/2001JB001739.

Basaltic Volcanism Study Project (1981), Basaltic Volcanism on the Terrestrial Planets, Pergamon, New York.

Beier, C., K. M. Haase, and T. H. Hansteen (2006), Magma evolution of the Sete Cidades volcano, São Miguel, Azores, J. Petrol., 47, 1375-1411.

Bergh, S. G., and E. S. Gudmunder (1991), Pleistocene massflow deposits of basaltic hyaloclastite on a shallow submarine shelf, South Iceland, Bull. Volcanol., 53, 597-611.

Borges, P. A. (2004), Ambientes litorais nos grupos Central e Oriental do arquipélago dos Açores, conteúdos e dinâmica de microescala, Ph.D. thesis, Univ. dos Açores, Ponta Delgada, Portugal.

Borges, P. A., J. V. Cruz, and C. F. Andrade (1997), O recuo da arriba litoral no local da Rocha dos Campos (Água d'Alto, São Miguel)—Um estudo de caso, Acoreana, 8, 391-401.

Bruno, B. C., G. J. Taylor, S. K. Rowland, P. G. Lucey, and S. Self (1992), Lava flows are fractals, Geophys. Res. Lett., 19, 305-308.

Bruno, B. C., G. J. Taylor, S. K. Rowland, and S. M. Baloga (1994), Quantifying the effect of rheology on lava-flow margins using fractal geometry, Bull. Volcanol., 56, 193-206.

Buforn, E., A. Udias, and M. A. Colombas (1988), Seismicity, source mechanisms and tectonics of the Azores-Gibraltar plate boundary, Tectonophysics, 152, 89-118.
Bull, J. M., T. A. Minshull, N. C. Mitchell, J. K. Dix, and J. Hardardottir (2005), Magmatic and tectonic history of Iceland's western rift zone at Lake Thingvallavatn, Geol. Soc. Am. Bull., 117, 1451-1465.

Calvari, S., and H. Pinkerton (1999), Lava tube morphology on Etna and evidence of lava flow emplacement mechanisms, J. Volcanol. Geotherm. Res., 90, 263-280.

Carracedo, J. C., S. J. Day, H. Guillou, and P. Gravestock (1999), Later stages of volcanic evolution of La Palma, Canary Islands: Rift evolution, giant landslides, and the genesis of the Caldera de Taburiente, Geol. Soc. Am. Bull., 111, $755-768$.

Cashman, K. V., and J. P. Kauahikaua (1997), Reevaluation of vesicle distributions in basaltic lava flows, Geology, 25, 419-422.

Chovelon, P. (1982), Évolution volcanotectonique des iles de Faial et de Pico, Archipel des Açores-Atlantique Nord, Ph.D. thesis, Univ. de Paris-Sud, Orsay, France.

Clague, D. A., and G. B. Dalrymple (1989), Tectonics, geochronology, and origin of the Hawaiian-Emperor volcanic chain, in The Geology of North America, vol. N, The Eastern Pacific Ocean and Hawaii, edited by E. L. Winterer, D. M. Hussong, and R. W. Decker, pp. 188-217, Geol. Soc. of Am., Boulder, Colo.

Clague, D. A., J. G. Moore, and J. R. Reynolds (2000), Formation of flat-topped volcanic cones in Hawai'i, Bull. Volcanol., 62, 214-233.

Clynne, M. A., D. E. Champion, D. A. Trimble, J. W. Hendley, and P. H. Stauffer (2000), How old is "Cinder Cone"?Solving a mystery in Lassen Volcanic National Park, California, Fact Sheet 023-00, U. S. Geol. Surv., Reston, Va.

Crown, D. A., and S. M. Baloga (1999), Pahoehoe toe dimensions, morphology, and branching relationships at Mauna Ulu, Kilauea Volcano, Hawaii, Bull. Volcanol., 61, 288-305.

Cruz, J. V., and M. O. Silva (2001), Hydrogeologic framework of Pico Island, Azores, Portugal, Hydrogeol. J., 9, 177-189.

Cunha, T. (2001), Tubos de lava na Ilha do Pico, Mundo Submerso, 58, 37-39.

Davis, J. C. (2002), Statistics and Data Analysis in Geology, 638 pp., John Wiley, New York.

Davis, M. G., M. O. Garcia, and P. Wallace (2003), Volatiles in glasses from Mauna Loa Volcano, Hawai'i: Implications for magma degassing and contamination, and growth of Hawaiian volcanoes, Contrib. Mineral. Petrol., 144, 570-591.

DeGraff, J. M., and A. Aydin (1987), Surface morphology of columnar joints and its significance to mechanics and direction of joint growth, Geol. Soc. Am. Bull., 99, 605-617.

de Silva, S. L., S. Self, P. W. Francis, R. E. Drake, and R. C. Ramirez (1994), Effusive silicic volcanism in the Central Andes: The Chao dacite and other young lavas of the Altiplano-Puna Volcanic Complex, J. Geophys. Res., 99, $17,805-17,826$.

Dragoni, M., I. Borsari, and A. Tallarico (2005), A model for the shape of lava flow fronts, J. Geophys. Res., 110, B09203, doi:10.1029/2004JB003523.

Duncan, A., J. E. Guest, E. R. Stofan, S. W. Anderson, H. Pinkerton, and S. Calveri (2004), Development of tumuli in the medial portion of the 1983 aa flow field, Mount Etna, Sicily, J. Volcanol. Geotherm. Res., 132, 173-187.

Fairbanks, R. C. (1989), A 17,000-year glacio-eustatic sealevel record: Influence of glacial melting rates on the Younger Dryas event and deep-ocean circulation, Nature, 342, 637-642.

Farr, T. G., and M. Kobrick (2000), Shuttle Radar Topography Mission produces a wealth of data, Eos Trans. $A G U$, 81, 583. 
Feraud, G., I. Kaneoka, and C. J. Allegre (1980), K/Ar ages and stress pattern in the Azores: Dynamic implications, Earth Planet. Sci. Lett., 46, 275-286.

Fernandes, R. M. S., L. Bastos, J. M. Miranda, N. Lourenço, B. A. C. Amrosius, R. Noomen, and W. Simons (2006), Defining the plate boundaries in the Azores region, J. Volcanol. Geotherm. Res., 156, doi:10.1016/j.jvolgeores.2006.03.019.

Field, M. E., and P. S. Roy (1984), Offshore transport and sand-body formation - evidence from a steep, high-energy shoreface, southeastern Australia, J. Sediment. Petrol., 54, $1292-1302$.

Fornari, D. J., A. Malahoff, and B. C. Heezen (1979), Submarine slope micromorphology and volcanic substructure of the island of Hawaii inferred from visual observations made during U. S. Navy deep-submergence vehicle (DSV) "Sea Cliff", Mar. Geol., 32, 1-20.

Fornari, D. J., J. P. Lockwood, P. W. Lipman, M. Rawson, and A. Malahoff (1980), Submarine volcanic features west of Kealakekua Bay, Hawaii, J. Volcanol. Geotherm. Res., 7, $323-337$.

França, Z. (2002), Origem e evolução petrológica e geoquímica do vulcanismo da Ilha do Pico-Açores, Ph.D. thesis, Univ. of the Azores, Ponta Delgada, Portugal.

França, Z., C. C. G. Tassinari, J. V. Cruz, A. Y. Aparicio, V. Araña, and B. N. Rodrigues (2006), Petrology, geochemistry and $\mathrm{Sr}-\mathrm{Nd}-\mathrm{Pb}$ isotopes of the volcanic rocks from Pico Island-Azores (Portugal), J. Volcanol. Geotherm. Res., 156, 71-89.

Freire Luis, J., J. M. Miranda, A. Galdeano, P. Patriat, J. C. Rossignol, and L. A. M. Victor (1994), The Azores triple junction evolution since $10 \mathrm{Ma}$ from an aeromagnetic survey of the Mid-Atlantic Ridge, Earth Planet. Sci. Lett., 125, 439-459.

Furnes, H., and I. B. Fridleifsson (1974), Tidal effects on the formation of pillow lava/hyaloclastite deltas, Geology, 2, $381-384$

Furnes, H., and B. A. Stuart (1976), Beach/shallow-marine hyaloclastite deposits and their geological significance - an example from Gran Canaria, J. Geol., 84, 439-453.

Gaonac'h, H., S. Lovejoy, and J. Stix (1992), Scale invariance of basaltic lava flows and their fractal dimensions, Geophys. Res. Lett., 19, 785-788.

Garcia, M. O., and M. G. Davis (2001), Submarine growth and internal structure of ocean island volcanoes based on submarine observations of Mauna Loa volcano, Hawaii, Geology, 29, 163-166.

Garcia, M. O., T. Hulsebosch, and J. M. Rhodes (1995), Olivine-rich submarine from the southwest rift zone of Mauna Loa volcano: Implications for magmatic processes and geochemical evolution, in Mauna Loa Revealed: Structure, Composition, History and Hazards, Geophys. Monogr. Ser., vol. 92, edited by J. M. Rhodes and J. P. Lockwood, pp. 219-239, AGU, Washington, D. C.

Garcia, M. O., E. H. Haskins, E. M. Stolper, and M. Baker (2007), Stratigraphy of the Hawai'i Scientific Drilling Project core (HSDP2): Anatomy of a Hawaiian shield volcano, Geochem. Geophys. Geosyst., 8, Q02G20, doi:10.1029/ 2006GC001379.

Gardner, T. W., D. W. Jorgensen, C. Shuman, and C. R. Lemieux (1987), Geomorphic and tectonic process rates: Effects of measured time interval, Geology, 15, 259-261.

Greeley, R. (1987), The role of lava tubes in Hawaiian volcanoes, U.S. Geol. Surv. Prof. Pap., 1350, 1589-1602.

Gregg, T. K. P., and W. W. Chadwick (1996), Submarine lavaflow inflation: A model for the formation of lava pillars, Geology, 24, 981-984.
Gregg, T. K. P., and J. H. Fink (1995), Quantification of submarine lava-flow morphology through analog experiments, Geology, 23, 73-76.

Gregg, T. K. P., and D. J. Fornari (1998), Long submarine lava flows: Observations and results from numerical modeling, J. Geophys. Res., 103, 27,517-27,531.

Gregg, T. K. P., and L. P. Keszthelyi (2004), The emplacement of pahoehoe toes: Field observations and comparison to laboratory simulations, Bull. Volcanol., 66, 381-391.

Gregg, T. K. P., and D. K. Smith (2003), Volcanic investigations of the Puna Ridge, Hawai'i: Relations of lava flow morphologies and underlying slopes, J. Volcanol. Geotherm. Res., 126, 63-77.

Griffiths, R. W. (2000), The dynamics of lava flows, Annu. Rev. Earth Planet. Sci., 32, 477-518.

Griffiths, R. W., and J. H. Fink (1992), Solidification and morphology of submarine lavas: A dependence on extrusion rate, J. Geophys. Res., 97, 19,729-19,737.

Guilbaud, M.-N., S. Self, T. Thordarson, and S. Blake (2005), Morphology, surface structures, and emplacement of lavas produced by Laki, A. D. 1783-1784, in Kinematics and Dynamics of Lava Flows, edited by M. Manga and G. Ventura, Spec. Pap. Geol. Soc. Am., 396, 81-102.

Heezen, B. C. (1977), Submarine geology from submersibles, in Submersibles and Their Use in Oceanography and Ocean Engineering, Elsevier Oceanogr. Ser., vol. 17, edited by R. A. Geyer, pp. 169-212, Elsevier, New York.

Hogarth, L. J., J. Babcock, N. W. Driscoll, N. L. Dantec, J. K. Haas, D. L. Inman, and P. M. Masters (2007), Long-term tectonic control on Holocene shelf sedimentation offshore La Jolla, California, Geology, 35, 275-278.

Hon, K., J. Kauahikaua, R. Denlinger, and K. Mackay (1994), Emplacement and inflation of pahoehoe sheet flows: Observations and measurements of active lava flows on Kilauea Volcano, Hawaii, Geol. Soc. Am. Bull., 106, 351-370.

Hon, K., C. Gansecki, and J. Kauahikaua (2003), The transition from 'a'a to Pahoehoe crust on flows emplaced during the Pu'u'O'o'Kupaianaha eruption, in The Pu'u 'O'o-Kupaianaha Eruption of Kilauea Volcano, Hawai' $i$ : The First 20 Years, edited by C. Heliker, D. A. Swanson, and T. J. Takahashi, U.S. Geol. Surv. Prof. Pap., 1676, 89-103.

Jeffreys, H. (1925), Flow of water in an inclined channel of rectangular section, Philos. Mag. J. Sci., 49, 793-807.

Jones, J. G. (1966), Intraglacial volcanoes of southwest Iceland and their significance in the interpretation of the form of marine basaltic volcanoes, Nature, 212, 586-588.

Keszthelyi, L., A. S. McEwen, and T. Thordarson (2000), Terrestrial analogs and thermal models for Martian flood lavas, J. Geophys. Res., 105, 15,027-15,050.

Kilburn, C. (1990), Surfaces of aa flow-fields on Mount Etna, Sicily: Morphology, rheology, crystallization and scaling phenomena, in Lava Flows and Domes: Emplacement Mechanisms and Hazard Implications, edited by J. H. Fink, pp. 129-156, Springer, New York.

Kilburn, C. R. J. (2004), Fracturing as a quantitative indicator of lava flow dynamics, J. Volcanol. Geotherm. Res., 132, 209-224.

Kilburn, C. R. J., and R. M. C. Lopes (1991), General patterns of flow field growth: Aa and blocky lavas, J. Geophys. Res., 96, 19,721-19,732.

Klein, E. M., and C. H. Langmuir (1987), Global correlations of ocean ridge basalt chemistry with axial depth and crustal thickness, J. Geophys. Res., 92, 8089-8115.

Klingelhöfer, F., M. Hort, H.-J. Kümpel, and H.-U. Schmincke (1999), Constraints on the formation of submarine lava flows 
from numerical model calculations, J. Volcanol. Geotherm. Res., 92, 215-229.

Kokelaar, B. P., and G. P. Durant (1983), The submarine eruption and erosion of Surtla (Surtsey), Iceland, J. Volcanol. Geotherm. Res., 19, 239-246.

Krastel, S., H.-U. Schmincke, and C. L. Jacobs (2001), Formation of submarine canyons on the flanks of the Canary Islands, Geo Mar. Lett., 20, 160-167.

Lee, H. J., M. E. Torresan, and W. McArthur (1994), Stability of submerged slopes on the flanks of the Hawaiian Islands, a simplified approach, U.S. Geol. Surv. Open File Report, 94-638, $54 \mathrm{pp}$.

Lescinsky, D. T., and O. Merle (2005), Extensional and compressional strain in lava flows and the formation of fractures in surface crust, in Kinematics and Dynamics of Lava Flows, edited by M. Manga and G. Ventura, Spec. Pap. Geol. Soc. Am., 396, 163-179.

Ligi, M., et al. (1999), Giant volcanic ridges amongst the Azores islands, Eos Trans. AGU, 80(46), Fall Meet. Suppl., F913.

Lipman, P. W., and J. G. Moore (1996), Mauna Loa lava accumulation rates at the Hilo drill site: Formation of lava deltas during a period of declining overall volcanic growth, J. Geophys. Res., 101, 11,631-11,641.

Lodato, L., L. Spampinato, A. Harris, S. Calvari, J. Dehn, and M. Patrick (2007), The morphology and evolution of the Stromboli 2002-2003 lava flow field: An example of a basaltic flow field emplaced on a steep slope, Bull. Volcanol., 69, 661-679.

Lourenço, N., J. M. Miranda, J. F. Luis, A. Ribeiro, L. A. M. Victor, J. Madeira, and H. D. Needham (1998), Morphotectonic analysis of the Azores volcanic plateau from a new bathymetric compilation of the area, Mar. Geophys. Res., 20, 141-156.

Luongo, G., A. Mazzarella, and G. Di Donna (2000), Multifractal characterization of Vesuvio lava flow margins and its implications, J. Volcanol. Geotherm. Res., 101, 307-311.

Machado, F., W. H. Parsons, A. F. Richards, and J. W. Mulford (1962), Capelinhos eruption of Fayal volcano, Azores 1957-1958, J. Geophys. Res., 67, 3519-3529.

Madeira, J., and A. Brumda Silveira (2003), Active tectonics and first paleoseismological results in Faial, Pico and S. Jorge islands (Azores, Portugal), Ann. Geophys., 46, 733-761.

Mark, R. K., and J. G. Moore (1987), Slopes of the Hawaiian Ridge, in Volcanism in Hawaii, edited by R. W. Decker, T. L. Wright, and P. H. Stauffer, U.S. Geol. Surv. Prof. Pap., 1350, $101-107$.

Masselink, G., and M. G. Hughes (2003), Introduction to Coastal Processes and Geomorphology, 354 pp., Arnold, London.

Menard, H. W. (1986), Islands, 230 pp., Sci. Am. Books, New York.

Mitchell, N. C. (2003), Susceptibility of mid-ocean ridge volcanic islands and seamounts to large-scale landsliding, J. Geophys. Res., 108(B8), 2397, doi:10.1029/2002JB001997.

Mitchell, N. C., and R. A. Livermore (1997), Extensive oblique faulting adjacent to the Conrad and Bouvet FZs near the Bouvet triple junction, Eos Trans. AGU, 78(46), Fall Meet. Suppl., F670.

Mitchell, N. C., M. A. Tivey, and P. Gente (2000), Slopes of mid-ocean ridge fault scarps from submersible observations, Earth Planet. Sci. Lett., 183, 543-555.

Mitchell, N. C., D. G. Masson, A. B. Watts, M. J. R. Gee, and R. Urgeles (2002), The morphology of the flanks of volcanic ocean islands: A comparative study of the Canary and Hawaiian hotspot islands, J. Volcanol. Geotherm. Res., 115, 83-107.
Mitchell, N. C., W. B. Dade, and D. G. Masson (2003), Erosion of the submarine flanks of the Canary Islands, J. Geophys. Res., 108(F1), 6002, doi:10.1029/2002JF000003.

Moore, J. G. (1975), Mechanism of formation of pillow lava, Am. Sci., 63, 269-277.

Moore, J. G. (2001), Density of basalt core from Hilo drill hole, Hawaii, J. Volcanol. Geotherm. Res., 112, 221-230.

Moore, J. G., and W. W. Chadwick (1995), Offshore geology of Mauna Loa and adjacent areas, Hawaii, in Mauna Loa Revealed: Structure, Composition, History and Hazards, Geophys. Monogr. Ser., vol. 92, edited by J. M. Rhodes and J. P. Lockwood, pp. 21-44, AGU, Washington, D. C.

Moore, J. G., and D. Clague (1987), Coastal lava flows from Mauna Loa and Hualalai volcanoes, Kona, Hawaii, Bull. Volcanol., 49, 752-764.

Moore, J. G., and R. S. Fiske (1969), Volcanic substructure inferred from dredge samples and ocean-bottom photographs, Hawaii, Geol. Soc. Am. Bull., 80, 1191-1202.

Moore, J. G., and D. J. Fornari (1984), Drowned reefs as indicators of the rate of subsidence of the Island of Hawaii, J. Geol., 92, 752-759.

Moore, J. G., R. L. Philips, R. W. Grigg, D. W. Peterson, and D. A. Swanson (1973), Flow of lava into the sea, 1969-1971, Kilauea volcano, Hawaii, Geol. Soc. Am. Bull., 84, 537-546.

Moore, J. G., D. J. Fornari, and D. A. Clague (1985), Basalts from the 1877 submarine eruption of Mauna Loa volcano, Hawaii: New data on the variation of the palagonitization rate with temperature, U.S. Geol. Surv. Bull., 1663, 1-11.

Moore, J. G., B. L. Ingram, K. R. Ludwig, and D. A. Clague (1996), Coral ages and island subsidence, Hilo drill hole, J. Geophys. Res., 101, 11,599-11,605.

Mouginis-Mark, P. J., S. K. Rowland, and H. Garbeil (1996), Slopes of western Galapagos volcanoes from airborne interferometric radar, Geophys. Res. Lett., 23, 3767-3770.

Müller, R. D., and W. R. Roest (1992), Fracture-zones in the North-Atlantic from combined GEOSAT and SEASAT data, J. Geophys. Res., 97, 3337-3350.

Neumann van Padang, M., A. F. Richards, F. Machado, T. Bravo, P. E. Baker, and R. W. Le Maitre (1967), Catalogue of the Active Volcanoes of the World Including Solfatara Fields, Part XXI, Atlantic Ocean, Int. Assoc. of Volcanol., Rome, Italy.

Norrman, J. O. (1980), Coastal erosion and slope development in Surtsey Island, Zeit. Geomorphologie, Suppl., 34, 20-38.

Nunes, J. C. (1999), A actividade vulcânica na Ilha do Pico do Plistocénico Superior ao Holocénico: Mecanismo eruptivo e hazard vulcânico, Ph.D. thesis, Univ. dos Acores, Ponta Delgada, Portugal.

Obata, S., and S. Umino (1999), Morphology of the A. D. 864 Aokigahara lava flow exposed on the coast of Motosuku Lake, Fiji Volcano (in Japanese), Bull. Volcanol. Soc. Jpn., 44, 201-216.

Peck, D. L., M. S. Hamilton, and H. R. Shaw (1977), Numerical-analysis of lava lake cooling models. 1. Application to Alae Lava Lake, Hawaii, Am. J. Sci., 277, 415-437.

Peterson, D. W. (1976), Process of volcanic island growth, Kilauea volcano, Hawaii, 1969-1973, in Symposium on Andes and Antarctic Volcanology Problems (Proceedings), pp. 172-189, Int. Assoc. of Volcanol. and Chem. of the Earth's Inter., Naples, Italy.

Pinkerton, H., and G. Norton (1995), Rheological properties of basaltic lavas at sub-liquidus temperatures: Laboratory and field measurements on lavas from Mount Etna, J. Volcanol. Geotherm. Res., 68, 307-323.

Pinkerton, H., and R. S. J. Sparks (1976), The 1975 sub-terminal lavas, Mount Etna: A case history of the formation of a 
compound lava field, J. Volcanol. Geotherm. Res., 1, 167182.

Pinkerton, H., and L. Wilson (1994), Factors controlling the lengths of channel-fed lava flows, Bull. Volcanol., 56, $108-$ 120.

Porebski, S. J., and R. Gradzinski (1990), Lava-fed Gilberttype delta in the Polonez Cove Formation (lower Oligocene), King George Island, West Antarctica, in Coarse-Grained Deltas, edited by A. Colella and D. B. Prior, Spec. Publ. Int. Assoc. Sedimentol., 10, 335-351.

Quartau, R., F. Curado, S. Bouriak, J. H. Monteiro, and L. Pinheiro (2003), Projecto Gemas-Localização e distribuição de areias em redor da ilha do Pico, Relatório Técnico INGMARDEP 16/2003, 49 pp., Dep. de Geol. Marinha, Geol. and Min. Inst., Lisbon, Portugal.

Quartau, R., H. Duarte, and P. Brito (2005), Projecto GemasRelatório da campanha de amostragem de sedimentos (FAPI3 ) realizada na plataforma e na orla costeira das ilhas do Faial e do Pico, Relatório Técnico INGMARDEP 2/2005, 17 pp., Dep. de Geol. Marinha e Costeira, Inst. Nac. de Eng., Tecnol. e Inovação I. P., Lisbon, Portugal.

Richards, A. F. (1960), Rates of marine erosion of tephra and lava at Isla San Benedicto, Mexico, Proc. XXI Int. Geol. Congr., 10, 59-64.

Richardson, L. F. (1961), The problem of contiguity: An appendix to statistics of deadly quarrels, Gen. Syst. Yearbook, $6,139-187$

Sansone, F. J., and J. R. Smith (2006), Rapid mass wasting following nearshore submarine volcanism on Kilauea volcano, Hawaii, J. Volcanol. Geotherm. Res., 151, 133-139.

Sansone, F. J., J. B. Culp, and R. L. Pyle (1990), Pele Meets the Sea, 27 min. videotape, LavaVideo Productions, Honolulu, Hawaii.

Scarth, A., and J.-C. Tanguy (2001), Volcanoes of Europe, 243 pp., Terra, Harpenden, U.K.

Schilling, J.-G. (1975), Azores mangle blob: Rare-earth evidence, Earth Planet. Sci. Lett., 25, 103-115.

Schmincke, H.-U., and U. Bednarz (1990), Pillow, sheet flow and breccia flow volcanoes and volcano-tectonic hydrothermal cycles in the extrusive series of the northeastern Troodos ophiolite (Cyprus), in Ophiolites: Oceanic Crustal Analogs, Proceedings of Symposium Troodos 1987, edited by J. Malpas et al., Geol. Surv. Dep., Nicosia, Cyprus.

Schmincke, H.-U., et al. (1995), Background, objectives, and principal results of drilling the clastic apron of Gran Canaria (VICAP), Proc. Ocean Drill. Program Initial Rep., 157, 1125.

Selby, M. J. (1993), Hillslope Materials and Processes, 451 pp., Oxford Univ. Press, Oxford, U.K.

Shaw, H. R., and J. G. Moore (1988), Magmatic heat and the El Nino cycle, Eos Trans. AGU, 69, 1553.

Soule, S. A., D. J. Fornari, M. R. Perfit, W. I. Ridley, M. H. Reed, and J. R. Cann (2006), Incorporation of seawater into mid-ocean ridge lava flows during emplacement, Earth Planet. Sci. Lett., 252, 289-307.

Sparks, R. S. J., and H. Pinkerton (1978), Effect of degassing on rheology of basaltic lava, Nature, 276, 385-386.

Spera, F. J. (2003), Physical properties of magma, in Encyclopedia of Volcanoes, edited by H. Sigurdsson et al., pp. 171190, Academic, San Diego, Calif.

Stasiuk, M. V., C. Jaupart, and R. S. J. Sparks (1993), Influence of cooling on lava-flow dynamics, Geology, 21, 335338.

Staudigel, H., and H.-U. Schmincke (1984), The Pliocene seamount series of La Palma/Canary Islands, J. Geophys. Res., $89,11,195-11,215$.
Stolper, E., and D. Walker (1980), Melt density and the average composition of basalt, Contrib. Mineral. Petrol., 74, $7-$ 12

Stretch, R., N. C. Mitchell, and R. A. Portaro (2006), A morphometric analysis of the submarine volcanic ridge of Pico Island, J. Volcanol. Geotherm. Res., 156, 35-54.

Sunamura, T. (1992), Geomorphology of Rocky Coasts, John Wiley, New York.

Swanson, D. (1973), Pahoehoe flows from the 1969-1971 Mauna Ulu eruption, Kilauea volcano, Hawaii, Geol. Soc. Am. Bull., 84, 615-626.

Tepley, L., and J. G. Moore (1974), Fire under the sea: The origin of pillow lava, 16-mm sound motion picture, Moonlight Prod., Mountain View, Calif.

Thors, K. (1992), Bedrock, sediments, and faults in Thingvallavatn, Oikos, 64, 69-79.

Tribble, G. W. (1991), Underwater observations of active lava flows from Kilauea Volcano, Hawaii, Geology, 19, 633-636.

Turcotte, D. L. (1997), Fractals and Chaos in Geology and Geophysics, 398 pp., Cambridge Univ. Press, Cambridge, U.K

Turcotte, D. L., and G. Schubert (1982), Geodynamics: Applications of Continuum Physics to Geological Problems, 450 pp., John Wiley, New York.

Umino, S. (2004), Lava flows of Fuji volcano (in Japanese), paper presented at International Symposium on Lava Flow Control and Disaster Mitigation, Yamanashi Inst. of Environ. Sci., Tokyo, Japan.

Umino, S., P. W. Lipman, and S. Obata (2000), Subaqueous lava flow lobes, observed on ROV Kaiko dives off Hawaii, Geology, 28, 503-506.

Umino, S., S. Obata, P. Lipman, J. R. Smith, T. Shibata, J. Naka, and F. Trusdell (2002), Emplacement and inflation structures of submarine and subaerial pahoehoe lavas from Hawaii, in Hawaiian Volcanoes: Deep Underwater Perspectives, Geophys. Monogr. Ser., vol. 128, pp. 85-101, AGU, Washington, D. C.

Umino, S., M. Nonaka, and J. Kauahikaua (2006), Emplacement of subaerial pahoehoe lava sheet flows into water: 1990 Kupaianaha flow of Kilauea volcano at Kaimu Bay, Hawai'i, Bull. Volcanol., 69, 125-139.

Urgeles, R., D. G. Masson, M. Canals, A. B. Watts, and T. Le Bas (1999), Recurrent large-scale landsliding on the west flank of La Palma, Canary Islands, J. Geophys. Res., 104, $25,331-25,348$.

Varnes, D. J. (1978), Slope movement types and processes, in Landslides, analysis and control, Special Report 176, edited by R. L. Schuster and R. J. Krizek, pp. 11-33, Natl. Acad. of Sci., Washington, D. C.

Vogt, P. R., and W. Y. Jung (2004), The Terceira Rift as a hyper-slow, hotspot-dominated oblique spreading axis: A comparison with other slow-spreading plate boundaries, Earth Planet. Sci. Lett., 218, 77-90.

Wadge, G. (1981), The variations of magma discharge during basaltic eruptions, J. Volcanol. Geotherm. Res., 11, 139168 .

Walker, G. P. L. (1973), Lengths of lava flows, Philos. Trans. R. Soc. London, Ser. A, 274, 107-118.

Walker, G. P. L. (1974), Volcanic hazards and the prediction of volcanic eruptions, in Prediction of Geological Hazards, edited by B. M. Funnell, Misc. Pap. 3, pp. 23-41, Geol. Soc., London, U.K.

Walker, G. P. L. (1991), Structure and origin by injection of lava under surface crust, of tumuli, "lava rises", "lava-rise pits", and "lava-inflation clefts" in Hawaii, Bull. Volcanol., $53,546-558$. 
Walker, G. P. L. (1992), Morphometric study of pillow-size spectrum among pillow lavas, Bull. Volcanol., 54, 459-474.

Wanless, V. D., M. O. Garcia, F. A. Trusdell, J. M. Rhodes, M. D. Norman, D. Weis, D. J. Fornari, M. D. Kurz, and H. Guillou (2006), Submarine radial vents on Mauna Loa Volcano, Hawai'i, Geochem. Geophys. Geosyst., 7, Q05001, doi:10.1029/2005GC001086.

Wessel, P., and W. H. F. Smith (1991), Free software helps map and display data, Eos, Transactions, $A G U, 72,441$.

White, J. D. L., and C. J. Busby-Spera (1987), Deep marine arc apron deposits and syndepositional magmatism in the Alisitos Group at Punta Cono, Baja California, Mexico, Sedimentology, 34, 911-928.
White, W. M., M. D. M. Tepia, and J.-G. Schilling (1979), The petrology and geochemistry of the Azores Islands, Contrib. Mineral. Petrol., 69, 201-213.

Woodhall, D. (1974), Geology and volcanic history of Pico Island Volcano, Azores, Nature, 248, 663-665.

Zbyszewski, G., C. Ribeiro Ferreira, O. da Veiga Ferreira, and C. Torre de Assunção (1963), Carta Geológica de Portugal. Ilha do Pico (Açores), Serv. Geol. de Portugal, Lisbon, Portugal.

Zhu, W., D. K. Smith, and L. G. J. Montési (2002), Effects of regional slope on viscous flows: A preliminary study of lava terrace emplacement at submarine volcanic rift zones, J. Volcanol. Geotherm. Res., 119, 145-159. 